\title{
Preparation of Porous Hydroxyapatite Using Cetyl Trimethyl Ammonium Bromide as Surfactant for the Removal of Lead Ions from Aquatic Solutions
}

\author{
Silviu-Adrian Predoi ${ }^{1,2}$, Carmen Steluta Ciobanu ${ }^{3, *}$, Mikael Motelica-Heino ${ }^{4}$, Mariana Carmen Chifiriuc ${ }^{5,6,7}$, $\mathbb{D}^{(D)}$, \\ Monica Luminita Badea ${ }^{3,8}$ and Simona Liliana Iconaru ${ }^{3, *}$
}

Citation: Predoi, S.-A.; Ciobanu, C.S.; Motelica-Heino, M.; Chifiriuc, M.C.; Badea, M.L.; Iconaru, S.L. Preparation of Porous Hydroxyapatite Using Cetyl Trimethyl Ammonium Bromide as Surfactant for the Removal of Lead Ions from Aquatic Solutions. Polymers 2021, 13, 1617. https://doi.org/ $10.3390 /$ polym 13101617

Academic Editors: Artur J.

M. Valente, Adam M. Paruch and Tanta-Verona Iordache

Received: 21 April 2021

Accepted: 11 May 2021

Published: 17 May 2021

Publisher's Note: MDPI stays neutral with regard to jurisdictional claims in published maps and institutional affiliations.

Copyright: (c) 2021 by the authors. Licensee MDPI, Basel, Switzerland. This article is an open access article distributed under the terms and conditions of the Creative Commons Attribution (CC BY) license (https:// creativecommons.org/licenses/by/ $4.0 /)$
1 Polytech Sorbonne, Sorbonne Universite, 4 Place Jussieu, 75005 Paris, France; silviuadrian00@gmail.com 2 Lycée Louis-le-Grand, 123 Rue Saint-Jacques, 75005 Paris, France

3 National Institute of Materials Physics, Atomistilor Street, No. 405A, P.O. Box MG 07, 077125 Magurele, Romania; monibadea78@gmail.com

4 ISTO, UMR 7327 CNRS Université d'Orléans, 1A rue de la Férollerie, CEDEX 2, 45071 Orléans, France; mikael.motelica@univ-orleans.fr

5 Life, Environmental and Earth Sciences Division, Research Institute of the University of Bucharest (ICUB), University of Bucharest, 060023 Bucharest, Romania

6 Microbiology Department, Faculty of Biology, University of Bucharest, 1-3 Portocalelor Lane, 77206 Bucharest, Romania

7 Academy of Romanian Scientists, Ilfov Street, No. 3, 50044 Bucharest, Romania

8 Faculty of Horticulture, University of Agronomic Sciences and Veterinary Medicine, 59 Mărăşti Blvd., 11464 Bucharest, Romania

* Correspondence: ciobanucs@gmail.com (C.S.C.); carmen.chifiriuc@gmail.com (M.C.C.); simonaiconaru@gmail.com (S.L.I.)

Abstract: In the present study, a new low-cost bioceramic nanocomposite based on porous hydroxyapatite (HAp) and cetyl trimethyl ammonium bromide (CTAB) as surfactant was successfully obtained by a simple chemical co-precipitation. The composition and structure of the HAp-CTAB were characterized by X-ray diffraction (XRD), Fourier transform infrared (FTIR) spectroscopy, transmission electron microscopy (TEM), scanning electron microscope (SEM) equipped with an energy dispersive X-ray (EDX) spectrometer, and $\mathrm{N}_{2}$ adsorption/desorption analysis. The capacity of HAp-CTAB nanocomposites to remove the lead ions from aqueous solutions was studied by adsorption batch experiments and proved by Langmuir and Freundlich models. The $\mathrm{Pb}^{2+}$ removal efficiency of $\mathrm{HAp}$ CTAB biocomposite was also confirmed by non-destructive ultrasound studies. The cytotoxicity assays showed that the HAp-CTAB nanocomposites did not induce any significant morphological changes of HeLa cells after $24 \mathrm{~h}$ of incubation or other toxic effects. Taken together, our results suggests that the obtained porous HAp-CTAB powder could be used for the decontamination of water polluted with heavy metals, such as $\mathrm{Pb}^{2+}$.

Keywords: adsorption; lead; hydroxyapatite; CTAB; removal; ultrasound studies

\section{Introduction}

In the recent years, one of the major issues affecting the public health area worldwide is the heavy metals contamination of waters. Heavy metals are non-biodegradable and tend to accumulate in living organisms. On the other hand, the excess of metals in the water stream could inflict severe diseases in people and have a negative impact on the environmental ecosystems [1-18]. One of the most current interests in science and public health policy worldwide is the lead carcinogenicity, which is significant for many populations around the globe. Despite the strict regulations on certain uses of lead, there are continuous environmental and occupational sources of exposure in many countries. The lead effects on the hematological system (e.g., inhibition of hemoglobin synthesis and altering of the red blood cells morphology and survival rate, with the occurrence of anemia) have been 
known and studied for years. $[19,20]$. In addition, studies regarding the toxic effects of lead against cell membrane components concluded that there is a direct correlation between the toxic effects and lead-induced oxidative damage [19-21].

The spreading of largely contaminated zones around the globe and especially the toxic effects of lead ions on human and environmental health have become of great concern. Therefore, great efforts and resources have been made by researchers around the world for finding new methods to resolve the lead pollution problem. One of the most recent studied methods for metals removal from wastewaters is the adsorption of metal ions [3-8] using various types of materials. The literature reports numerous studies that showed that apatites (particularly hydroxyapatite, due to its unique structure that confers a strong affinity for various metal ions) could successfully remove metal ions from aqueous solutions $[3,9,10]$.

Recently, surface porogen agents such as chitosan [11], cellulose [12,13], tetraethoxysilane [3], methyltrimethoxysilane [14], etc., have been used for the development of hydroxyapatite-based materials, to increase their adsorption capacity. All these materials have been proposed to be used for aqueous solutions decontamination. Cetyltrimethylammonium bromide (CTAB) was recently proposed as a porogen material used to improve the adsorption capacity of phosphate ceramics. In their study, García et al. [15] reported the use of a new type of microemulsion system based on CTAB/toluene/n-butanol/water for the preparation of hexagonal hydroxyapatite under hydrothermal conditions. The study reported obtaining hydroxyapatite particles with a good population, with typical hexagonal prism-like morphology, with an average particle size around $100 \mathrm{~nm}$. These results are in agreement with other reported studies regarding the obtaining of CTAB-HAp nanocomposites.

Furthermore, Liu et al. [16] also reported that they have successfully developed hydroxyapatite with a needle-like structure in the presence of $\mathrm{CTAB}$, and they have also concluded that in the absence of CTAB and PEG 400, HAp was obtained in the form of particles. In addition, their study concluded that the additions of CTAB, $\mathrm{PEG} 400, \mathrm{NH}_{3} \mathrm{OH}$, and ethanoic acid are crucial for the formation of the nanorods in the nanocomposites. Furthermore, another study conducted by Shih et al. [17], regarding the synthesis of HAp powders, revealed that the addition of $\mathrm{CTAB}$ had an important role in the size of the synthesized powders, allowing the obtaining of particle sizes around $20 \mathrm{~nm}$. Nonetheless, until now, just a few studies regarding the utilization of CTAB in the development of composites used for water decontamination have been reported [18]. On the other hand, the utilization of porous phosphate ceramics-based CTAB in water decontamination is not cited in the literature. Therefore, our studies will contribute to fill a knowledge gap regarding the better understanding of the mechanisms and processes that are underlying the adsorption process of metals by porous phosphate ceramics.

The goal of this study was to prepare a new low-cost HAp-CTAB nanocomposite. The use of CTAB as a surfactant has contributed both to the stabilization of HAp and to the creation of more active centers on the surface, thus contributing to the increase of the adsorption capacity of lead ions from contaminated waters. Besides, in this study, the adsorption isotherms and equilibrium of the adsorption processes were considered. Furthermore, the efficacy of HAp-CTAB in removing lead ions from contaminated aqueous solutions has been demonstrated for the first time by non-destructive ultrasound studies.

\section{Materials and Methods}

\subsection{Materials}

Cetyltrimethylammonium bromide $\left(\left(\mathrm{C}_{16} \mathrm{H}_{33}\right) \mathrm{N}-\left(\mathrm{CH}_{3}\right)_{3} \mathrm{Br}, \mathrm{CTAB}\right)$, calcium nitrate $\left(\mathrm{Ca}\left(\mathrm{NO}_{3}\right)_{2} \cdot 4 \mathrm{H}_{2} \mathrm{O}\right)$, ammonium dihydrogen phosphate $\left(\left(\mathrm{NH}_{4}\right)_{2} \mathrm{HPO}_{4}\right)$, ammonium hydroxide $\left(\mathrm{NH}_{3} \cdot \mathrm{H}_{2} \mathrm{O}\right)$, and deionized water were purchased from Merck (Merck, Kenilworth, NJ, USA). 


\subsection{Sample Synthesis}

In order to prepare the $\mathrm{HAp}-\mathrm{CTAB}$ composite $(\mathrm{Ca} / \mathrm{P}$ molar ratio equal to 1.67), the $\mathrm{CTAB}$ and $\mathrm{Ca}\left(\mathrm{NO}_{3}\right)_{2} \cdot 4 \mathrm{H}_{2} \mathrm{O}$ was dissolved in $300 \mathrm{~mL}$ deionized water resulting Ca-CTABcontaining solution $(9 \mathrm{~g})$. The $\left(\mathrm{NH}_{4}\right)_{2} \mathrm{HPO}_{4}$ was dissolved in $300 \mathrm{~mL}$ deionized water resulting P-containing solution. The P-containing solution was added drop by drop into the Ca-CTAB-containing solution and stirred for $6 \mathrm{~h}$. The $\mathrm{pH}$ value was continually adjusted at 10 during the reaction. The resulting precipitate was washed five times with deionized water. After washing, the precipitate was centrifuged and the HAp-CTAB composite was dried at $100{ }^{\circ} \mathrm{C}$ for $24 \mathrm{~h}$.

\subsection{Characterization of HAp-CTAB Composite}

\subsubsection{X-ray Diffraction (XRD)}

The X-ray diffraction (XRD) pattern of the HAp-CTAB composite was recorded on a Bruker D8 Advance diffractometer with nickel-filtered $\mathrm{Cu} \mathrm{K} \alpha(\lambda=1.5418 \AA)$ radiation (Billerica, MA, USA). The sample was measured at room temperature. The scanning range was $20-60^{\circ}$ in $2 \theta$. The incremental step was $0.02^{\circ}$ while the time per step was $0.4 \mathrm{~s}$. The average crystal size of the HAp-CTAB composite powder was calculated using the Scherrer equation [22]:

$$
\Gamma=(0.94 \cdot \lambda) /(\mathrm{D} \cos \theta)
$$

where $\Gamma$ is the full-width at half-maximum (FWHM), $\lambda$ is the X-ray wavelength, D is the crystal size, and $\theta$ is the Bragg angle for the reflection (002).

\subsubsection{Fourier Transform Infrared Spectroscopy (FT-IR)}

FTIR studies were conducted using a Spectrum BX spectrometer (Perkin Elmer, Waltham, MS, USA). In order to acquire the spectra of analyzed nanoparticles, $1 \%$ nanopowder was mixed and ground with $99 \% \mathrm{KBr}$. Pellets of $10 \mathrm{~mm}$ diameter were prepared by pressing the powder mixture. The spectrum was taken in the range of 400 to $4000 \mathrm{~cm}^{-1}$ with a resolution of $4 \mathrm{~cm}^{-1}$.

\subsubsection{Transmission Electron Microscopy (TEM)}

Studies regarding the morphology and particle size of the HAp-CTAB nanocomposites were performed with the aid of a CM 20 (Philips FEI, Eindhoven, The Netherlands) transmission electron microscope (TEM), equipped with a Lab6 instrument.

\subsubsection{Scanning Electron Microscopy (SEM)}

Furthermore, the morphology of the HAp-CTAB nanocomposites was also investigated using a scanning electron microscopy (SEM) with the aid of a Hitachi S4500 instrument (Hitachi, Tokyo, Japan). In addition, the chemical constituents of the nanocomposites were measured with the aid of energy-dispersive X-ray spectroscopy (EDS).

\subsection{5. $\mathrm{N}_{2}$ Adsorption/Desorption Analysis}

$\mathrm{N}_{2}$ adsorption/desorption analysis of HAp-CTAB ceramics were conducted using a Micromeritics ASAP 2020 automatic analyzer at 77K. The sample was degassed at $450 \mathrm{~K}$ for $24 \mathrm{~h}$ before the measurement. The specific surface area (SSA) was calculated by the Barrett-Emmett-Teller (BET) equation [23]. The adsorption cumulative surface area, the pore size, and volume distribution were calculated based on the Barrett-Joyner-Halenda (BJH) model [24].

\subsection{Evaluation of the Efficiency of HAp-CTAB Composite in Decontamination}

\subsubsection{Non-Destructive Ultrasound Studies}

In order to assess the efficiency of HAp-CTAB composite in removing lead from contaminated waters, ultrasonic studies were conducted on the contaminated solutions before and after the removal of lead ions. The signals were obtained using two identical 
transducers. The frequency of the two transducers was $5 \mathrm{MHz}$ and the distance between them was $30 \mathrm{~mm}$. Ninety-one signals were recorded. Three echoes were measured for each recorded signal. To evaluate the efficiency of the HAp-CTAB composite in removing lead from contaminated waters, double distilled water was used as a reference in ultrasonic studies. Ultrasound pulses [25] were used to investigate both lead-contaminated solutions and solutions obtained after lead removal by the use of HAp-CTAB composite.

\subsubsection{Batch Adsorption Experiments}

In order to assess the capacity of the HAp-CTAB nanoparticles of retaining lead ions from contaminated solutions, batch adsorption experiments were performed. The experiments were conducted at room temperature and in atmospheric conditions using 40 $\mathrm{mL}$ silicon tubes filled with lead-contaminated aqueous solutions. The lead concentration in the aqueous solutions varied from 0 to $100 \mathrm{mg} / \mathrm{L}$, and the amount of HAp-CTAB powder was kept at $0.2 \mathrm{~g}$. The $\mathrm{pH}$ of contaminated aqueous solutions was constantly adjusted to 5 with the aid of a solution hydrochloric acid $(\mathrm{HCl})$, with a concentration of 0.1 M. For the experiments, the solution volume was kept at $20 \mathrm{~mL}$. A Mixer SRT1 Roller (Stuart Scientific, Staffordshire, UK) was used to shake the silicone tubes containing the contaminated solutions and HAp-CTAB nanocomposites for $24 \mathrm{~h}$ in atmospheric condition at a temperature of $25 \pm 2{ }^{\circ} \mathrm{C}$. After $24 \mathrm{~h}$, the mixtures were centrifuged at 10,000 rpm, and the supernatant was filtered, recovered, and analyzed by Flame Atomic Absorption Spectrometry (AAS) using a Zeeman HITACHI Z-8100 from Japan Hitachi (Tokyo, Japan) instrument. The AAS investigations were performed in triplicate at a wavelength of 283.3 $\mathrm{nm}$ in agreement with the operational conditions for lead.

The adsorption kinetics investigations were evaluated using both Langmuir and Freundlich adsorption models [26-30]. The amount of adsorbed metal ions onto the adsorbent at equilibrium, $\mathrm{Q}_{\mathrm{e}}(\mathrm{mg} / \mathrm{g})$, was calculated according to:

$$
\mathrm{Q}_{\mathrm{e}}=\frac{\left(\mathrm{C}_{\mathrm{i}}-\mathrm{C}_{\mathrm{e}}\right)}{\mathrm{m}} \cdot \mathrm{V}
$$

where $C_{i}$ and $C_{e}(m g / L)$ depicts the initial and equilibrium $\mathrm{Pb}^{2+}$ concentrations in $\mathrm{mg} / \mathrm{L}$, $\mathrm{V}(\mathrm{L})$ represents the volume of the solution and $\mathrm{m}(\mathrm{g})$ stands for the mass of the HApCTAB. Furthermore, the percentage removal of lead ions from aqueous solutions using HAp-CTAB nanoparticles ( $\mathrm{R} \%$ ) was calculated from the equation:

$$
R(\%)=\frac{\left(C_{i}-C_{e}\right)}{C_{i}} \cdot 100
$$

in which $C_{i}$ and $C_{e}$ are the initial and equilibrium concentrations of the contaminant ions in $\mathrm{mg} / \mathrm{L}$.

Information regarding the adsorption process were obtained by determining the Langmuir constants, $\mathrm{q}_{\mathrm{m}}$ and $\mathrm{K}_{\mathrm{L}}$ using the graphical representation of the linear Langmuir equation:

$$
\frac{\mathrm{C}_{\mathrm{e}}}{\mathrm{Q}_{\mathrm{e}}}=\frac{1}{\left(\mathrm{q}_{\mathrm{m}} \cdot \mathrm{K}_{\mathrm{L}}\right)}+\frac{\mathrm{C}_{\mathrm{e}}}{\mathrm{q}_{\mathrm{m}}}
$$

Moreover, with the aid of the determined constants, $R_{L}$, the separation factor constant, known also as the equilibrium parameter, was determined from the equation:

$$
\mathrm{R}_{\mathrm{L}}=\frac{1}{1+\mathrm{K}_{\mathrm{L}} \mathrm{C}_{\mathrm{i}}}
$$

Additional studies about the adsorption kinetics of lead ions onto HAp-CTAB nanocomposites were performed using the Freundlich isotherm experimental model described by the following equation:

$$
\mathrm{Q}_{\mathrm{e}}=\mathrm{k}_{\mathrm{f}} \cdot \mathrm{C}_{\mathrm{e}}^{\frac{1}{\mathrm{n}}}
$$


where $Q_{e}$ represents the amount of lead ions adsorbed at equilibrium in $\mathrm{mg} / \mathrm{g}$, Ce is the metal ion concentration at equilibrium expressed in $\mathrm{mg} / \mathrm{L}$, and $\mathrm{k}_{\mathrm{f}}[\mathrm{mg} / \mathrm{g}(\mathrm{mg} / \mathrm{L})-1 / \mathrm{n}]$ and $n$ are the Freundlich constants. The Freundlich constants, $k_{f}$ and $n$, representing the adsorption capacity and the adsorption intensity of the adsorbent, were obtained from the graphical representation $\left(\ln Q_{e}\right)$ function of $\left(\ln C_{e}\right)$ of the linear form of the Freundlich equation

$$
\ln Q_{e}=\ln k_{f}+\frac{1}{n} \ln C_{e}
$$

\subsection{Biological Investigation}

The in vitro evaluation of the HAp-CTAB cytotoxicity was performed using the MTT (3-4,5-Dimethylthiazol 2,5-diphenyltetrazolium bromide) assay. The MTT assay was performed as previously reported [31-34]. The cytotoxicity of the HAp-CTAB was performed using HeLa cells. The viability of the HeLa cells was investigated after being treated for $24 \mathrm{~h}$ with HAp-CTAB nanoparticles as well as lead-contaminated and decontaminated solutions. HeLa cell viability was quantified by measuring the absorbance of the suspensions at a wavelength of $595 \mathrm{~nm}$ using a TECAN spectrophotometer (Tecan GENios, Grödic, Germany). The MTT assays were performed in triplicate and the results were presented as mean $\pm \mathrm{SD}$ (standard deviation). The morphology of the HeLa cells was also investigated by optical microscopy after $24 \mathrm{~h}$ of incubation with the HAp-CTAB nanoparticles as well as contaminated and decontaminated solutions before and after the lead ions removal batch adsorption experiments.

\section{Results}

The X-Ray Diffraction (XRD) patterns shown in Figure 1 exhibited that the diffraction peaks of (002), (102), (210), (211), (300), (202), (310), (222), (213), and (004) can be assigned to the standard data (JCPDS No. 9--432) of single phase hexagonal hydroxyapatite with the space group of $P 6_{3 / \mathrm{m}}$. The XRD patterns shown in Figure 1 exhibited that the diffraction peaks of (002), (102), (210), (211), (300), (202), (310), (222), (213), and (004) can be assigned to the standard data (JCPDS No. 9-432) of single phase hexagonal hydroxyapatite with the space group of $\mathrm{P} 63 / \mathrm{m}$. The calculated values of lattice parameters of HAp-CTAB composite were $\mathrm{a}=\mathrm{b}=9.43 \AA$ and $\mathrm{c}=6.86 \AA$ that were in agreement with the lattice parameters of pure hydroxyapatite $\mathrm{a}=\mathrm{b}=9.4166 \AA, \mathrm{c}=6.8745 \AA$. The value obtained for lattice parameters were in good accordance with the previous studies $[35,36]$. The average crystallite size of HAp-CTAB powder was $20.5 \pm 1 \mathrm{~nm}$. In the XRD patterns showed in Figure 1, no other secondary phase was observed, which highlights the fact that the existence of CTAB did not affect the product structure.

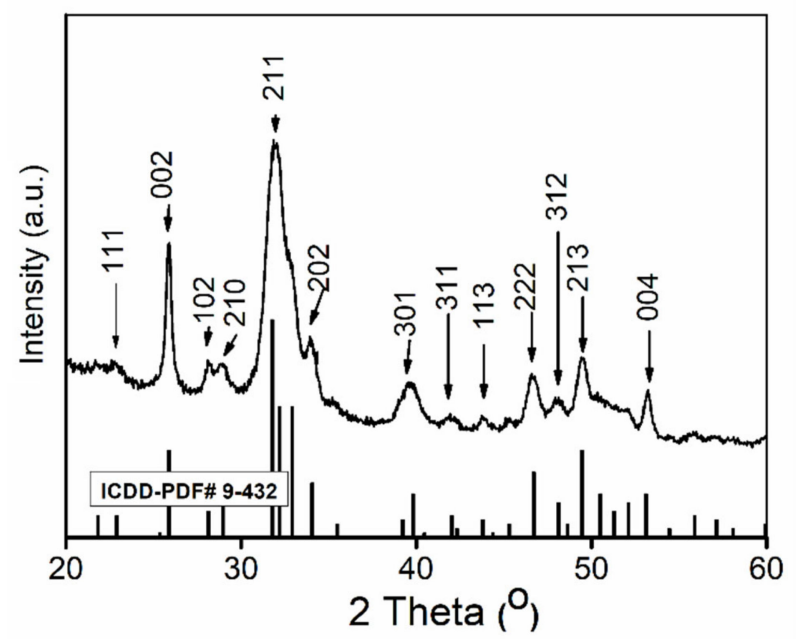

Figure 1. X-Ray Diffraction (XRD) patterns of the HAp-CTAB nanocomposite. 
The Fourier Transform Infrared Spectroscopy (FT-IR) spectra of CTAB and HApCTAB were presented ion Figure 2. As can be seen in Figure 2, the bands of $2850 \mathrm{~cm}^{-1}$ $\left(v^{\mathrm{a}}(\mathrm{C}-\mathrm{H})\right)$ and $2918 \mathrm{~cm}^{-1}\left(v^{\mathrm{as}}(\mathrm{C}-\mathrm{H})\right)$ were observable only in the CTAB spectrum. On the other side, the spectrum of HAp-CTAB exhibited the vibrations of the $\mathrm{PO}_{4}{ }^{3-}$ as well as $\mathrm{OH}^{-}$functional groups. The peak at $474 \mathrm{~cm}^{-1}$ was assigned to $v_{3}$ phosphate stretching modes while the peak at $1040 \mathrm{~cm}^{-1}$ was attributed to $v_{2}$ phosphate bending mode. The presence of $v_{4}$ phosphate bending mode was revealed by the peaks at 566 and $604 \mathrm{~cm}^{-1}$. The characteristic peaks at 1399 and $1390 \mathrm{~cm}^{-1}$ in the spectra of CTAB and HAp-CTAB were assigned to $\delta\left(\mathrm{NH}_{4}{ }^{+}\right)$. The peaks at 3015 and $3130 \mathrm{~cm}^{-1}$ in the spectra of CTAB and HAp-CTAB were attributed to $\mathrm{NH}_{4}{ }^{+}\left(v\left(\mathrm{NH}_{4}{ }^{-}\right)\right.$. The presence in the spectra of peaks at around $1390 \mathrm{~cm}$ and in the region $3000-3150 \mathrm{~cm}^{-1}$ highlighted the existence of ammonium salt. The existence of adsorbed water in the samples was revealed by the broad bands at around $3650 \mathrm{~cm}^{-1}$ in FT-IR spectra of CTAB and $3568 \mathrm{~cm}^{-1}$ in FT-IR spectra of HAp-CTAB. The band at $1663 \mathrm{~cm}^{-1}$ (FT-IR spectrum of HAp-CTAB) was assigned to the presence of adsorbed water. The peaks associated to the FTIR spectrum of CTAB located in the range of $890-110 \mathrm{~cm}^{-1}$ could not be observed in the FTIR spectrum of HAp-CTAB composite due to broad bands present in this region and associated with $\mathrm{PO}_{4}{ }^{3-}$ vibrations. The achieved results were in accordance with preceding studies [35,37-41] confirming the formation of the HAp-CTAB composite.
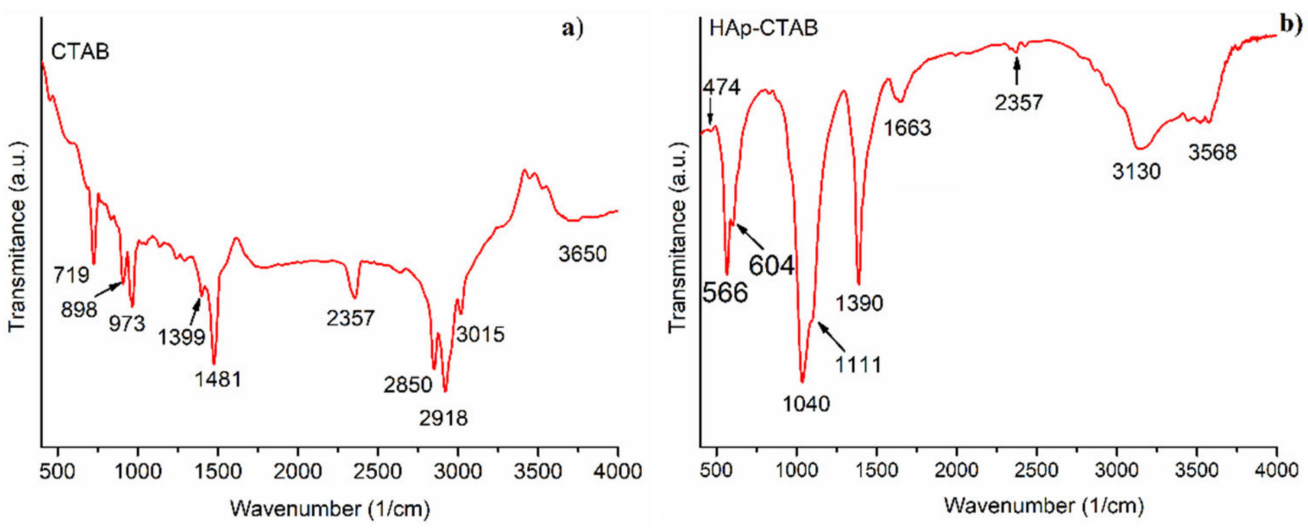

Figure 2. Fourier Transform Infrared Spectroscopy (FT-IR) spectra of CTAB (a) and HAp-CTAB composite (b).

The morphology of the HAp-CTAB nanocomposites has been examined by scanning electron microscopy (SEM). The SEM micrographs and the EDS spectra as well as the elemental distribution map of the HAp-CTAB particles are presented in Figure 3a-d. The SEM images of HAp-CTAB showed that the particles exhibit nanometric dimensions and an almost ellipsoidal morphology (Figure $3 a, b)$. On the other hand, the energydispersive X-ray spectroscopy (EDS) spectrum depicted the chemical composition of the HAp-CTAB nanocomposites. In the EDS spectrum, the main chemical constituents of HAp-CTAB, namely calcium $(\mathrm{Ca})$, phosphorus $(\mathrm{P})$, oxygen $(\mathrm{O})$, nitrogen $(\mathrm{N})$, and bromine $(\mathrm{Br})$, were evidenced (Figure 3d). Furthermore, the EDS elemental map showed that the main constituents ( $\mathrm{Ca}, \mathrm{P}, \mathrm{O}, \mathrm{N}$ and $\mathrm{Br}$ ) are uniformly distributed in the sample (Figure 3c). 


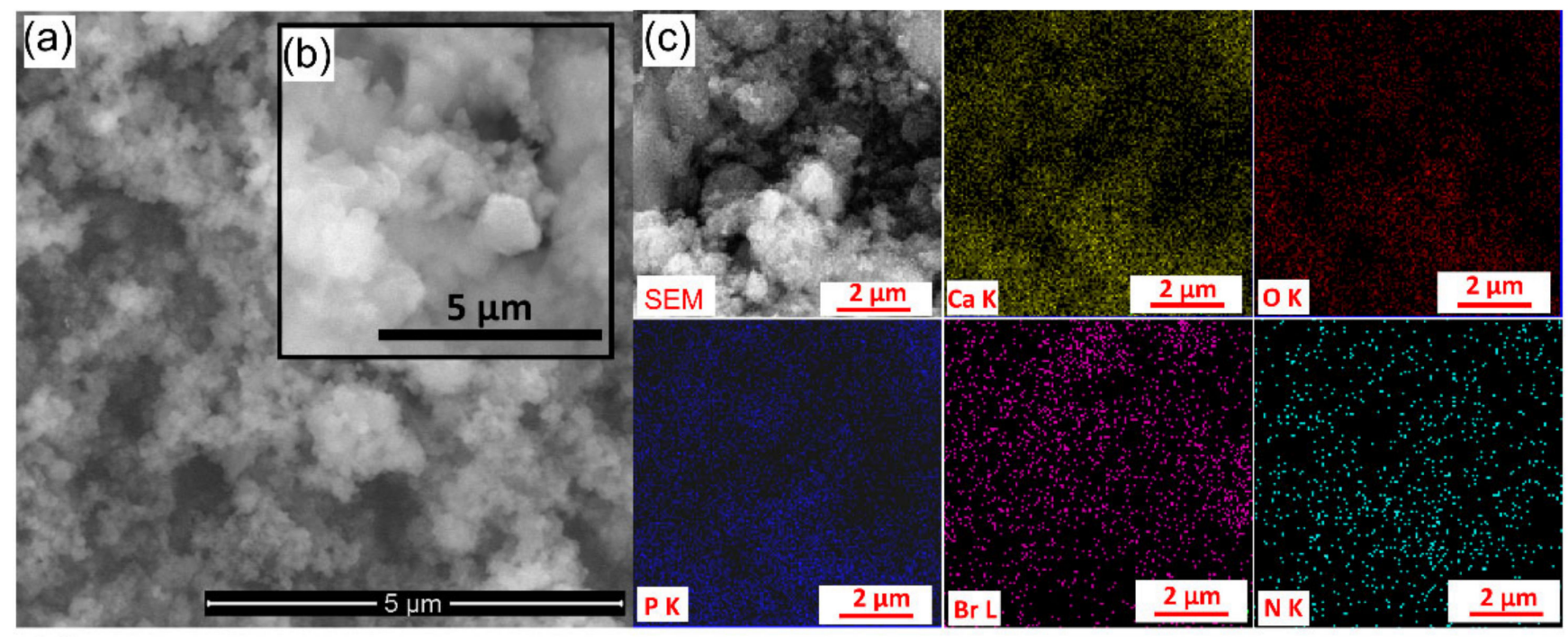

(d)

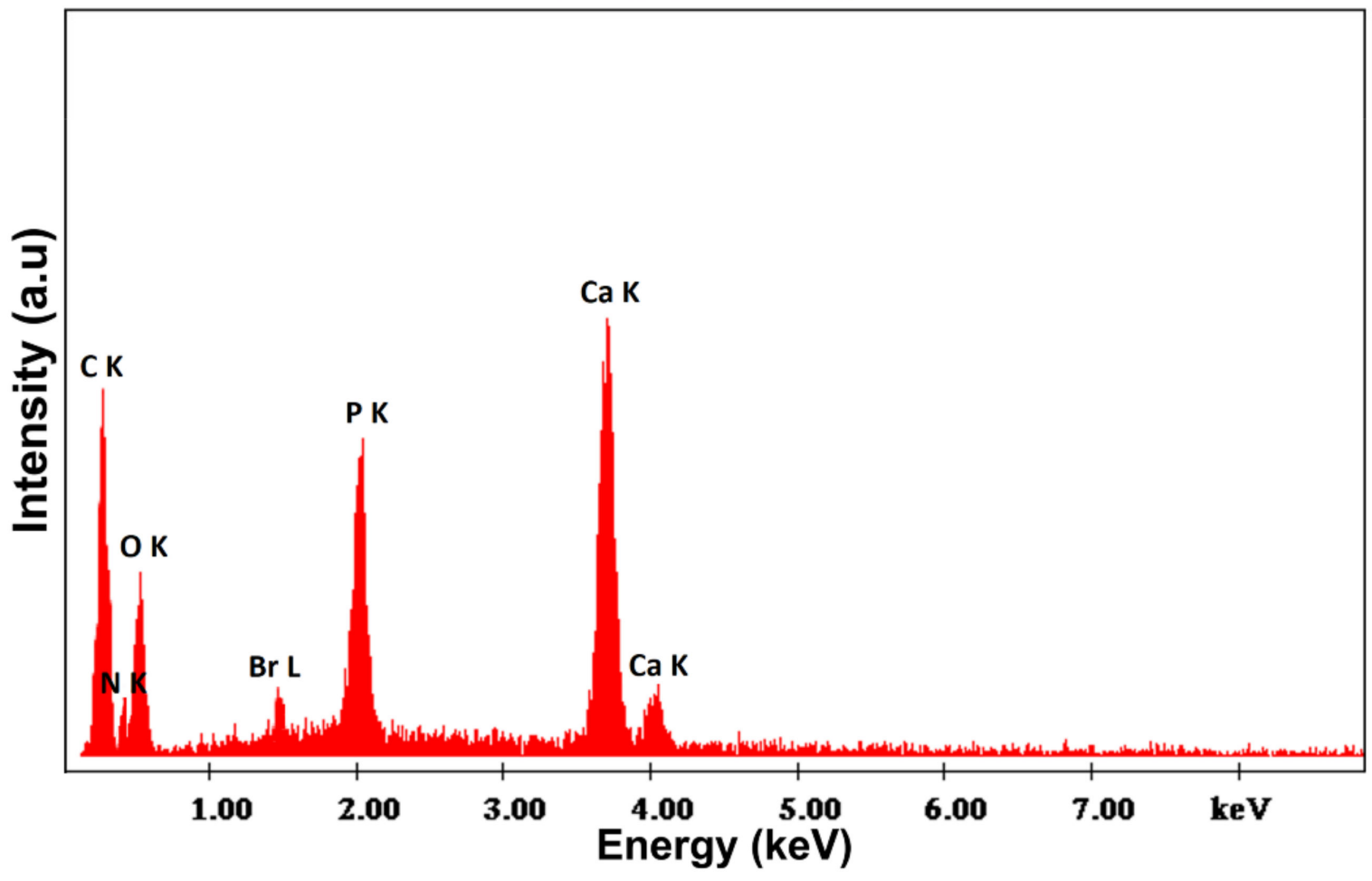

Figure 3. Scanning electron microscopy (SEM) micrograph and zoom area of SEM micrograph (a,b), SEM micrographs of elemental distribution and elemental distribution maps (c), and energy-dispersive X-ray spectroscopy (EDS) spectra (d) of HAp-CTAB nanocomposites.

Furthermore, additional information regarding the morphology of the HAp-CTAB nanocomposites was obtained by transmission electron microcopy (TEM). Figure $4 \mathrm{a}, \mathrm{b}$ depicts the TEM and HRTEM image of the HAp-CTAB particles. The TEM investigations revealed that the particles have nanometric sizes and present ellipsoidal morphology. Moreover, the HRTEM image emphasized that the nanocomposites exhibit a uniform ellipsoidal morphology with nanometric particle size. The TEM results are in agreement with the SEM findings. 

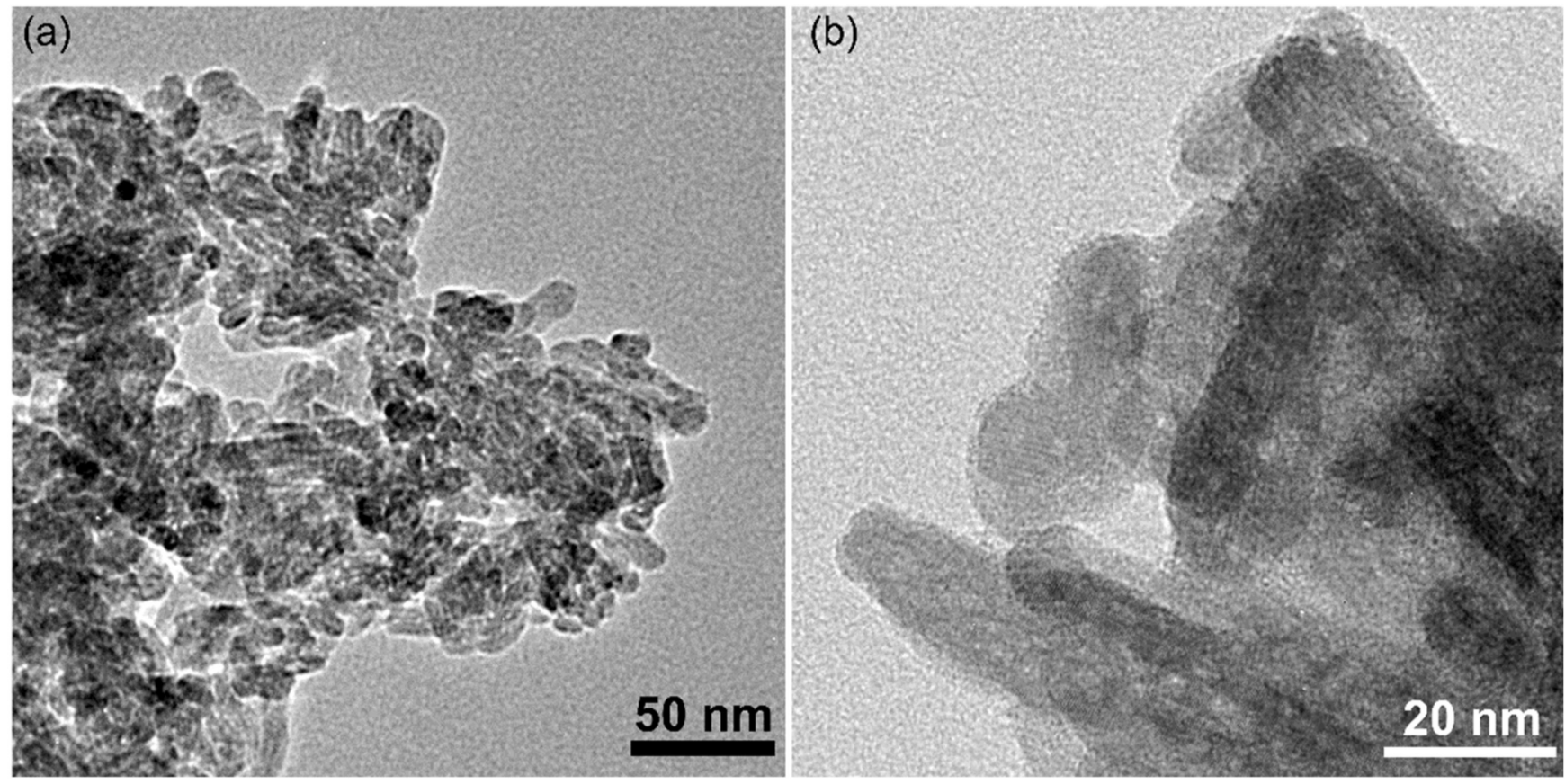

Figure 4. Transmission electron microcopy (TEM) (a) and High resolution transmission electron microcopy (HRTEM) (b) image of HAp-CTAB nanocomposites.

Figure 5 presents the specific surface area (SSA) and pore size distribution determined by $\mathrm{N}_{2}$ adsorption isotherm. The HAp-CTAB sample exhibits a similar type of IV isotherms according to the IUPAC nomenclature [42]. This behavior is typical for mesoporous materials. Brunauer-Emmett-Teller (BET) SSA of HAp-CTAB composite was $145.8335 \mathrm{~m}^{2} / \mathrm{g}$ with pore volume of $0.4825 \mathrm{~cm}^{3} / \mathrm{g}$. The BJH adsorption cumulative surface area was found to be $173.1174 \mathrm{~m}^{2} / \mathrm{g}$. According to previous studies [43-45] it was found that the SSA of HAp-CTAB composite was higher that has been previously reported on hydroxyapatite-based materials. In agreement with J. Silvestre-Albero et al. [43], the condensation of the pores indicates that the gas was condensed in a liquid-like phase and this process takes place at a pressure " $\mathrm{p}$ " lower than the saturation pressure $\mathrm{p}_{\mathrm{o}}$ of the liquid in bulk. The extensive and broader hysteresis loop was supported by the Barrett-JoynerHalenda (BJH) adsorption dv/dw pore volume as exhibited in Figure $5 b$. During the BJH adsorption, the pore diameter was $12.02 \mathrm{~nm}$.
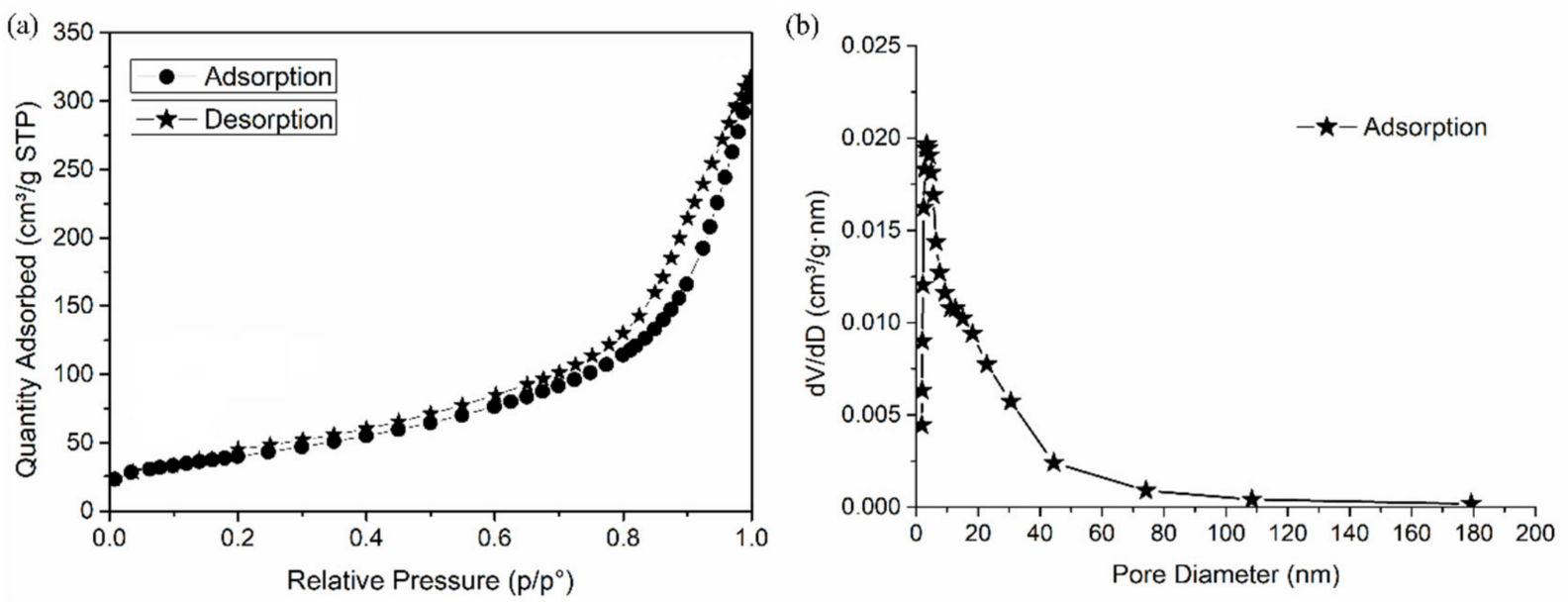

Figure 5. $\mathrm{N}_{2}$ adsorption-desorption isotherms (a) and pore size distribution graphs (b) of HAp-CTAB composite. 
The capacity of the HAp-CTAB nanocomposites in retaining lead ions from aqueous solutions was studied using flame atomic absorption spectroscopy. The batch adsorption experiments were performed in triplicate at room temperature. The evaluation of the capacity of HAp-CTAB in removing lead ions removal from aqueous solutions was performed by keeping in contact for $24 \mathrm{~h}, 0.2 \mathrm{~g}$ of HAp-CTAB nanocomposites with lead-contaminated solutions. The removal efficiency of $\mathrm{Pb}^{2+}$ ions by $\mathrm{HAp}-\mathrm{CTAB}$ nanocomposites was calculated from the data obtained in the batch adsorption experiments.

Figure 6 depicts the effect of $\mathrm{Pb}^{2+}$ ions concentration from the contaminated solutions on the removal of lead ions from aqueous solutions using $0.2 \mathrm{~g}$ of HAp-CTAB nanocomposites. The results have emphasized that the percentage of removal efficiency $(\mathrm{R} \%)$ is strongly correlated with the initial concentration of $\mathrm{Pb}^{2+}$. The data suggested that for a contaminated solution with above $10 \mathrm{mg} / \mathrm{L}$ of $\mathrm{Pb}^{2+}$, the removal efficiency was higher than $99 \%$. The results highlighted that the HAp-CTAB nanocomposites exhibited a strong affinity for $\mathrm{Pb}^{2+}$ ions.

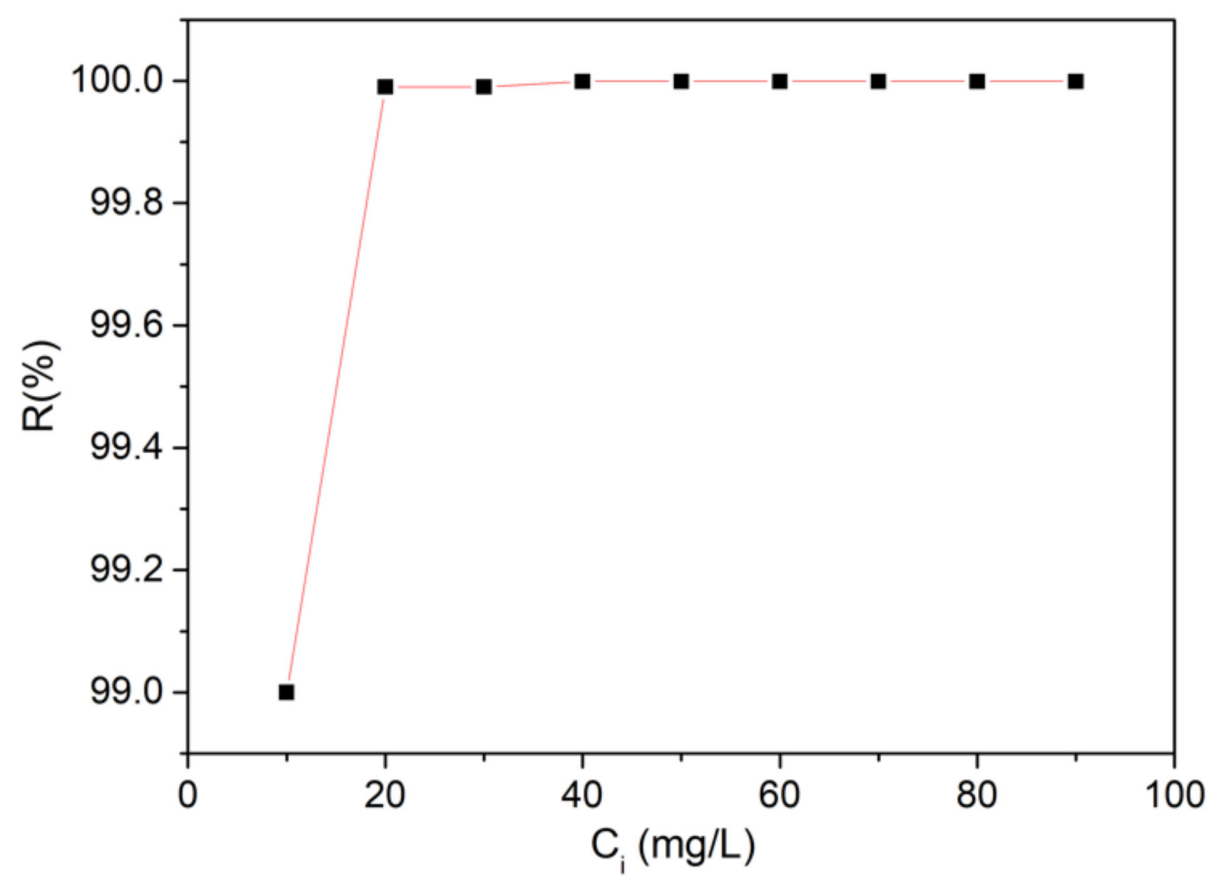

Figure 6. Removal percentage of $\mathrm{Pb}^{2+}$ ions from contaminated solutions using HApCTAB nanocomposites.

Recently, various decontamination technologies based on the processes of adsorption of metal ions on different materials have been widely proposed in the literature [46-50]. The adsorption processes have often been described by various models such as Langmuir, Temkin, Toth, Freundlich, Hill, etc. [51]. All the models used for describing adsorption processes state that the kinetics plays a very important role in the understanding of the mechanisms involved [52]. The models combine the physico-chemical parameters of the adsorbent and thermodynamic assumptions, thus revealing important information regarding the adsorption mechanisms, surface properties, and also the affinity of the adsorbent [53].

The adsorption process's kinetics of lead ions by HAp-CTAB nanocomposites were described using both Langmuir and Freundlich adsorption models [26,54].

The data used to compute the isotherms for the lead ions removal using HAp-CTAB nanocomposites were obtained by mixing solutions containing different concentrations of $\mathrm{Pb}^{2+}$ with a fix amount $(0.2 \mathrm{~g})$ of HAp-CTAB nanocomposites until the reach of the thermodynamic equilibrium. The experiments were performed at ambient temperature 
$\left(\mathrm{T}=25 \pm 2{ }^{\circ} \mathrm{C}\right.$ ). The obtained data were used to determine the adsorption capacity, which is defined as the amount of metal retained per mass unit.

The Langmuir model of adsorption which was originally elaborated for the description of the activated carbon gas-solid adsorption phase has also been employed for the quantification of the efficiency of numerous materials used as adsorbents [52]. The empirical model proposed by Langmuir depicts a monolayer adsorption and also describes a process of adsorption that could only happen for a finite number of localized and previously defined areas, which are identical and equivalent $[55,56]$. The experimental data and the theoretical Langmuir model for the lead ions adsorption from aqueous solutions using HAp-CTAB nanocomposites is presented in Figure 7.

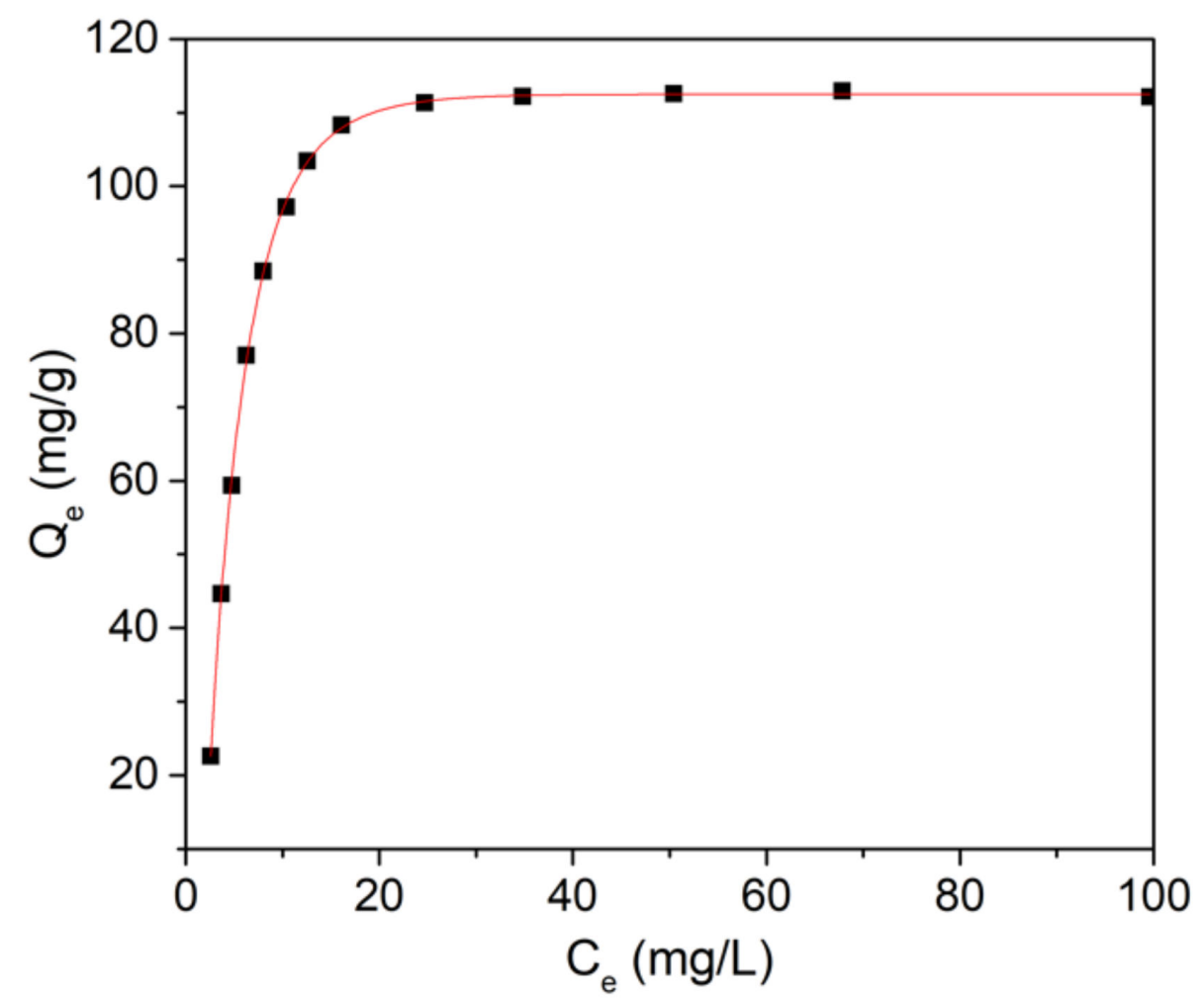

Figure 7. Graphical representation of the amount of material adsorbed at equilibrium by the equilibrium concentration for the adsorption of $\mathrm{Pb}^{2+}$ from contaminated aqueous solutions using HApCTAB nanocomposites.

Figure 7 presents the graphical representations of the $\mathrm{Pb}^{2+}$ adsorbed ions by HApCTAB nanocomposites, on the mass unit $\left(\mathrm{Q}_{e}\right)$ function of the concentration of the $\mathrm{Pb}^{2+}$ ions that remained in the contaminated solution after $24 \mathrm{~h}\left(\mathrm{C}_{\mathrm{e}}\right)$. Furthermore, the Langmuir constants, maximum adsorption capacity $\left(\mathrm{q}_{\mathrm{m}}\right)$, and the constant energy associated with the heat of adsorption $\left(\mathrm{K}_{\mathrm{L}}\right)$ were determined from the graphical representation of the linear form of the Langmuir equation depicted in Figure 8a. 

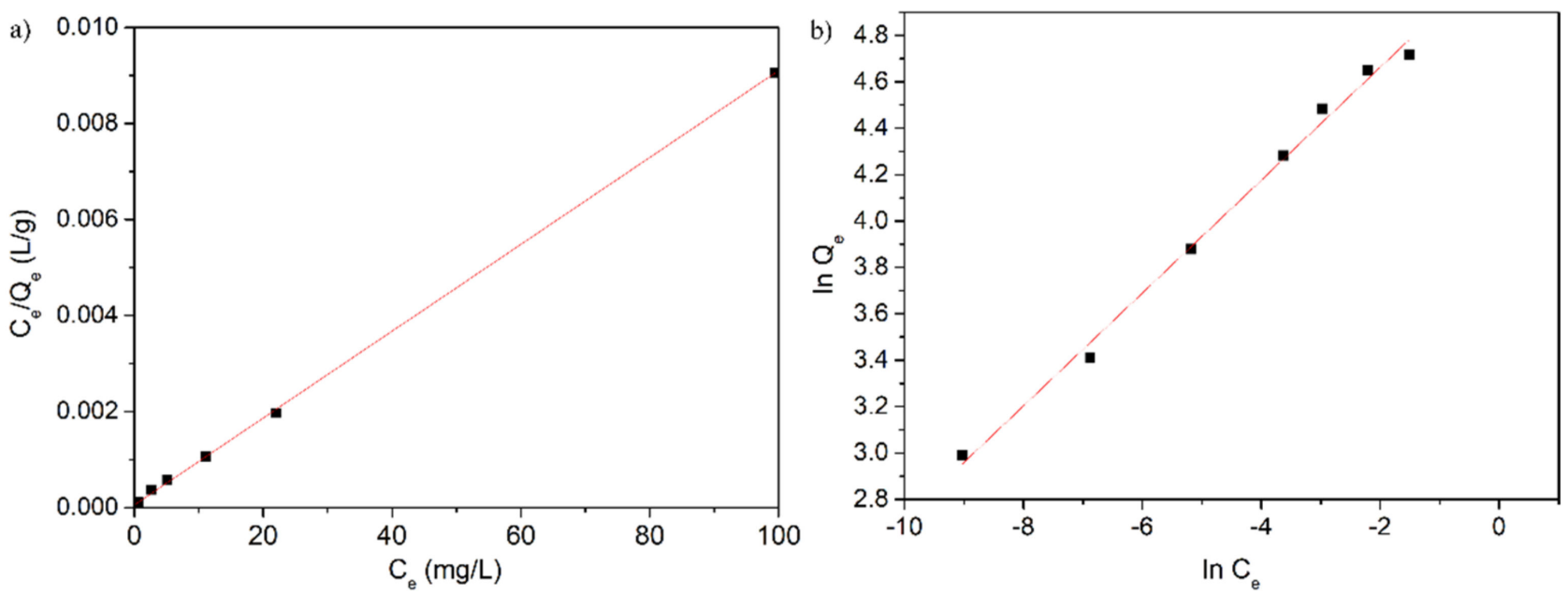

Figure 8. Langmuir (a) and Freundlich (b) graphical linearized equations for the adsorption of lead ions on HApCTAB nanocomposites.

The data suggested that at ambient temperature, the $\mathrm{R}^{2}$ coefficient computed from the Langmuir model isotherm data was equal to 0.999 for HAp-CTAB. These results proved that the Langmuir model fits the data obtained from the batch adsorption experiments well. The results obtained in this study are in concordance with previous reported data on the use of hydroxyapatite based nanocomposites for lead ions adsorption from contaminated aqueous solutions [14,57-60]. As in previous studies [61,62], the transformation of the nonlinear isothermal Langmuir equation into a linear form using a nonlinear method was performed and the Langmuir constants were calculated.

Recently, numerous studies have been undertaken and their results on the capacity of apatites and hydroxyapatite-based materials to retain metal ions from aqueous solutions were reported in the literature [57-60,63]. Based on the experimental conditions, the physico-chemical properties of the materials and adsorption parameters, the adsorption capacity of $\mathrm{Pb}^{2+}$ ions using hydroxyapatite or hydroxyapatite based materials was reported in the range of 84-620 $\mathrm{mg} \mathrm{g}^{-1}$ [63]. The results obtained from the batch adsorption experiments data revealed that HAp-CTAB nanocomposites have been extremely successful in removing $\mathrm{Pb}^{2+}$ ions from aqueous solutions. The Langmuir constants determined from the data revealed a value of $110.5 \mathrm{mg}(\mathrm{Pb}) / \mathrm{g}$ for the adsorption capacity and a value of $166.49 \mathrm{~L} / \mathrm{mg}$ for the $\mathrm{K}_{\mathrm{L}}$ coefficient. In addition, the Freundlich model was also used in order to better understand the mechanisms involved in the removal of lead ions using HAp-CTAB nanocomposites. The Freundlich adsorption isotherm is often used in the case of a non-ideal and reversible adsorption mechanism. In the Freundlich model, the adsorption is not limited to a monolayer formation and could be applied in multilayer adsorption [63-65]. The graphical representations of $\left(\ln Q_{e}\right)$ function of $\left(\operatorname{lnC}_{e}\right)$ for the lead ion adsorption experiments on HAp-CTAB nanocomposites is represented in Figure 8b. The Freundlich constant, $\mathrm{k}_{\mathrm{f}}$, depicts the adsorption capacity of the materials used as adsorbent, and the $1 / \mathrm{n}$ represents the function of the power adsorption from the process [66]. Figure $8 \mathrm{~b}$ presents the Freundlich linearized equation for the adsorption of lead ions on HAp-CTAB nanocomposites. In the Freundlich model, if the Freundlich constant, n, is equal to 1 , then the separation of the two phases is independent of the concentration, while a $1 / \mathrm{n}$ value below 1 depicts a normal adsorption process and $1 / \mathrm{n}$ value less than 1 indicates a cooperative adsorption process [67].

The values obtained for the Langmuir and Freundich parameters from the adsorption batch experiments are presented in Table 1. 
Table 1. Langmuir and Freundlich isotherm parameters for $\mathrm{Pb}^{2+}$ adsorption onto HApCTAB nanocomposites.

\begin{tabular}{ccccccc}
\hline Sample & \multicolumn{3}{c}{ Langmuir } & \multicolumn{3}{c}{ Freundlich } \\
\hline \multirow{2}{*}{ HAp-CTAB } & $\mathbf{R}^{\mathbf{2}}$ & $\mathbf{q}_{\mathbf{m}}(\mathbf{m g} / \mathbf{g})$ & $\begin{array}{c}\mathbf{K}_{\mathbf{L}} \\
(\mathbf{L} / \mathbf{m g})\end{array}$ & $\mathbf{R}^{2}$ & $\mathbf{n}$ & $\mathbf{k}_{\mathbf{f}}$ \\
\cline { 2 - 7 } & 0.999 & 110.5 & 166.49 & 0.993 & 4.11 & 172.25 \\
\hline
\end{tabular}

The value from $\mathrm{n}$ determined using the linearized form of the Freundlich equation, for the $\mathrm{Pb}^{2+}$ ions adsorption experiments on HAp-CTAB nanocomposites, were higher than 1 . These results lead to a value of $1 / \mathrm{n}$ below 1 , which suggested a normal adsorption process. Furthermore, the $\mathrm{R}_{\mathrm{L}}$ separation factors, which indicates the shape of the isotherm, was also determined using the Freundlich parameters [64]. The $\mathrm{R}_{\mathrm{L}}$ values equal to 1 depict a linear isotherm, while $R_{L}$ values higher than 1 describe an unfavorable isotherm and a $R_{L}$ value situated between 0 and 1 , is associated with a favorable isotherm. A value of $R_{L}$ equal to 0 describes an irreversible isotherm. In the present study, the value of the $R_{L}$ determined from the batch adsorption experiments data was between 0 and 1 , depicting a favorable adsorption of $\mathrm{Pb}^{2+}$ on $\mathrm{HAp}-\mathrm{CTAB}$ nanocomposites. Moreover, the data highlighted that the uptake of $\mathrm{Pb}^{2+}$ on $\mathrm{HAp}-\mathrm{CTAB}$ nanocomposites at room temperature and at $\mathrm{pH} 5$ was high, due to the affinity that is relatively large between $\mathrm{Pb}^{2+}$ and HAp-CTAB nanocomposites. Moreover, taking into consideration the correlation coefficients $\left(R^{2}\right)$ determined from fitting the experimental data using both Langmuir and Freundlich theoretical models, it was observed that the experimental equilibrium data of $\mathrm{Pb}^{2+}$ sorption onto HAp-CTAB nanocomposites was best described using the Langmuir model. The results of the batch experiments and the data obtained using Langmuir and Freundlich models suggested that $\mathrm{HAP}-\mathrm{CTAB}$ nanocomposites presented a strong affinity for the adsorption of $\mathrm{Pb}^{2+}$ ions from aqueous solutions, therefore rendering HAp-CTAB nanocomposites good candidates in the development of new technologies for water treatment.

An ultrasonic characterization was performed on both polluted and depolluted samples in order to acquire information about the efficiency of removing lead ions from contaminated waters. This method of analysis is non-invasive and can provide information about the solid particles in the analyzed liquid. Since water is considered to be the most stable fluid, we chose double-distilled water as a reference fluid because of its high purity. Ultrasonic measurements revealed properties of the samples by studying the behavior of the spectral amplitudes. Their attenuation in time provided important information about the stability of the analyzed fluid. The effect of HAp-CTAB in removing lead ions from contaminated water is presented below using double-distilled water as a reference for all measured and analyzed signals.

Figure $9 \mathrm{a}, \mathrm{d}$ reveals the amplitude of the signals obtained at each moment in the interval 0-300 s, before and after the removal of the lead from the contaminated water. The signals were registered at $5 \mathrm{~s}$ intervals for lead-contaminated water (a) and decontaminated water (d). The constant peak amplitudes of the first echo is presented in color. The second and third echoes were significantly weaker and are shown in black. 
(a)

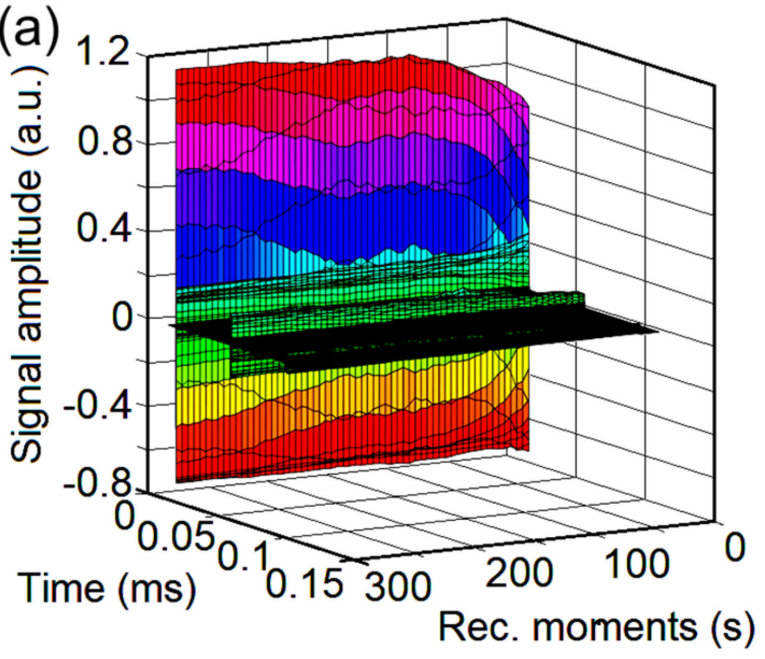

(b)

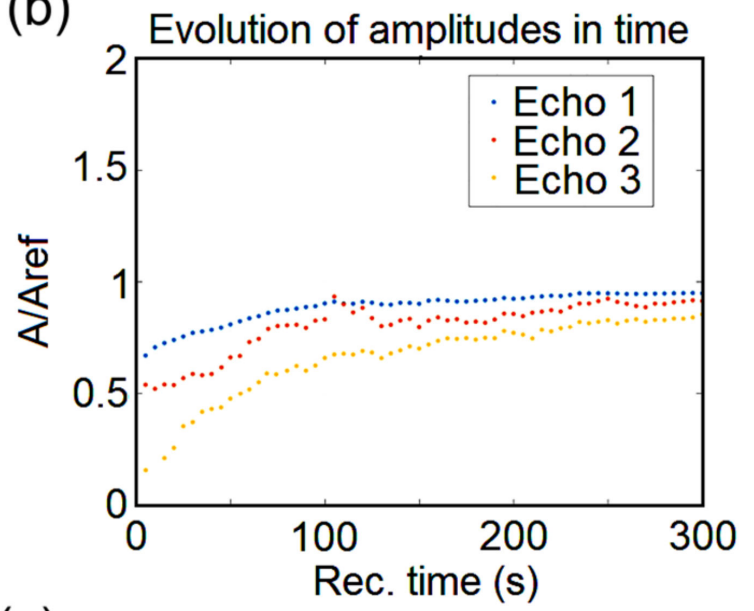

(c)

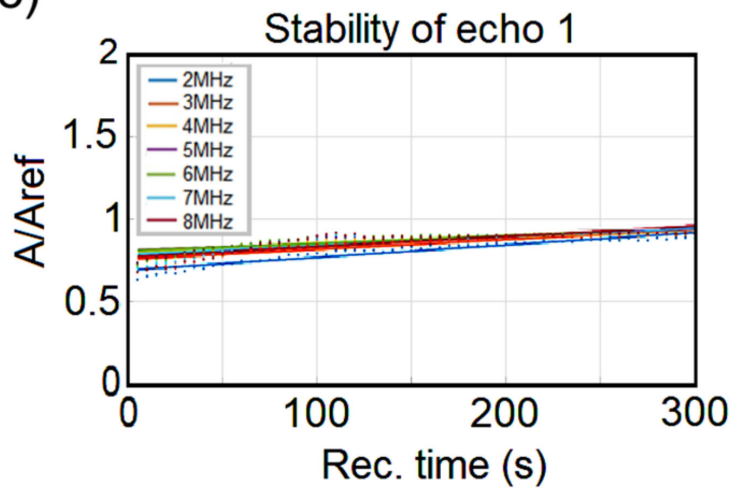

(d)

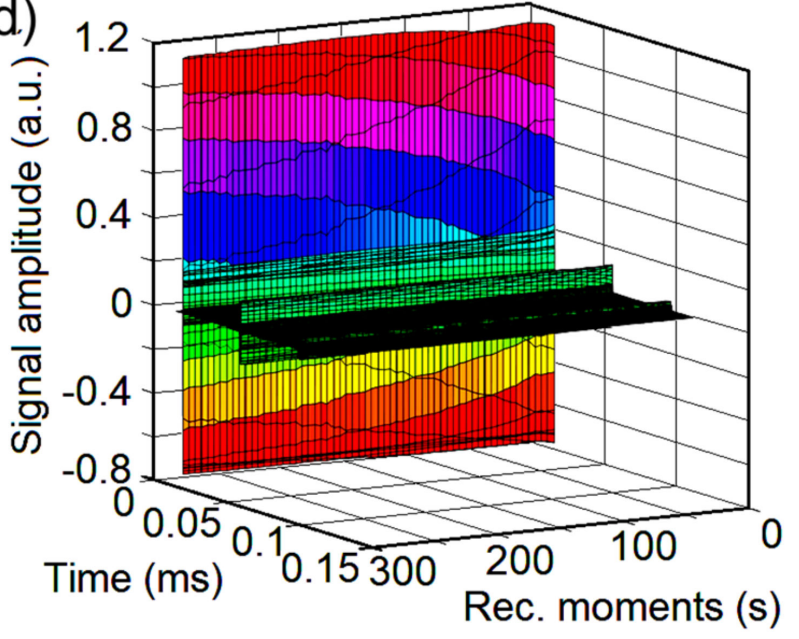

(e)

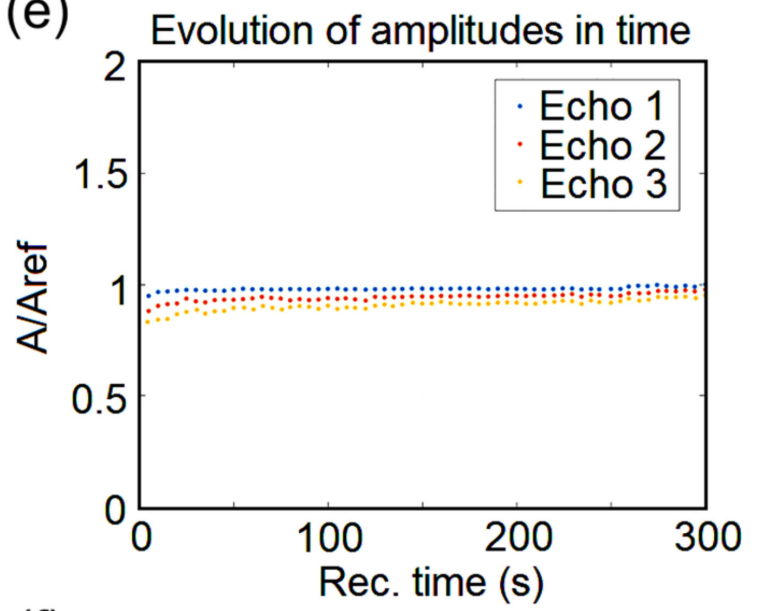

(f)

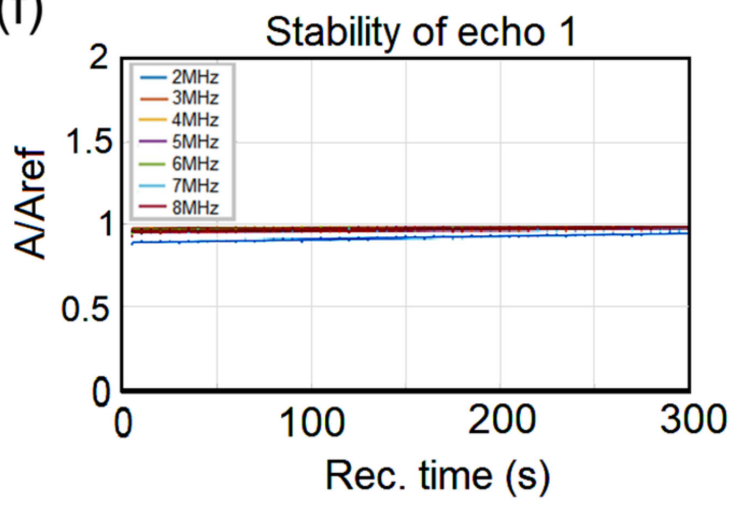

Figure 9. Acquired signals before (a) and after (d) lead removal. Evolution of amplitude in time before (b) and after lead removal (e); stability of echo 1 before (c) and after (f) lead removal.

(Figure 9b,e) illustrates how the relative spectral amplitudes (RSA) of the three desired echoes change with time. The reference used for the amplitudes is water $\left(\mathrm{A}_{\text {ref }}\right)$. For the sample representing lead-contaminated water, the relative amplitude $\left(A / A_{\text {ref }}\right)$ of the three echoes is much lower than 1 even at Rec.time $=300$ s (Figure 9b). After decontamination (Figure 9e), it is observed that all three analyzed echoes have $\left(\mathrm{A} / \mathrm{A}_{\text {ref }}\right) \in[0.8 ; 1]$ for $\operatorname{Rec}$. Time $(s) \in[0 ; 40]$. Also, from Figure 9e, there is $\left(A / A_{\text {ref }}\right) \in[0.9 ; 1]$ for Rec.Time $(s) \in$ $[40 ; 150]$. Furthermore, for Rec. Time $(\mathrm{s}) \gg 150,\left(\mathrm{~A} / \mathrm{A}_{\text {ref }}\right) \approx 1$. It is noticed (Figure 9e) that after decontamination, for the first echo, $\left(\mathrm{A} / \mathrm{A}_{\text {ref }}\right)$ varies slowly from 0.98 to 1 for Rec.Time $(s) \in[50 ; 250]$. Considering the fact that $\left(A / A_{\text {ref }}\right)=1$ for the signal through 
double-distilled water, it can be said that the biocomposite HAp-CTAB has a very good efficiency in removing lead from the contaminated water.

As it could be observed, the presence of the pollutant renders the sample unstable. In order to track the stability of the samples, Figure 9c,f shows how the RSA of echo 1 varies as function of time, over several frequencies, before/after decontamination. For the contaminated water (Figure 9c), a divergence was noticed for all frequencies compared to the double distilled water (whose equilibrium value has been taken as reference). The values of the RSA for echo 1 in decontaminated water were constant at 1 (Figure 9f). This result showed that the analyzed water after decontamination has the same behavior to that of double distilled water. Consequently, it can be said that this study certifies the effectiveness of HAp-CTAB in lead removal from water.

It has been observed by signal analysis that echo 1 has the highest accuracy, due to its direct path between the transducers. For this reason, the rest of the analysis concerns only echo 1 in all recorded signals (Figure 10a-c). The behavior of the spectral amplitudes for echo 1 (Figure 10a) in the case of polluted water indicates a visible convergence in time towards the reference across all spectra, from lower to higher amplitudes. On the other hand, it can be observed that the spectral amplitude of the decontaminated water is very close to that of the reference (Figure 10c).

(a)

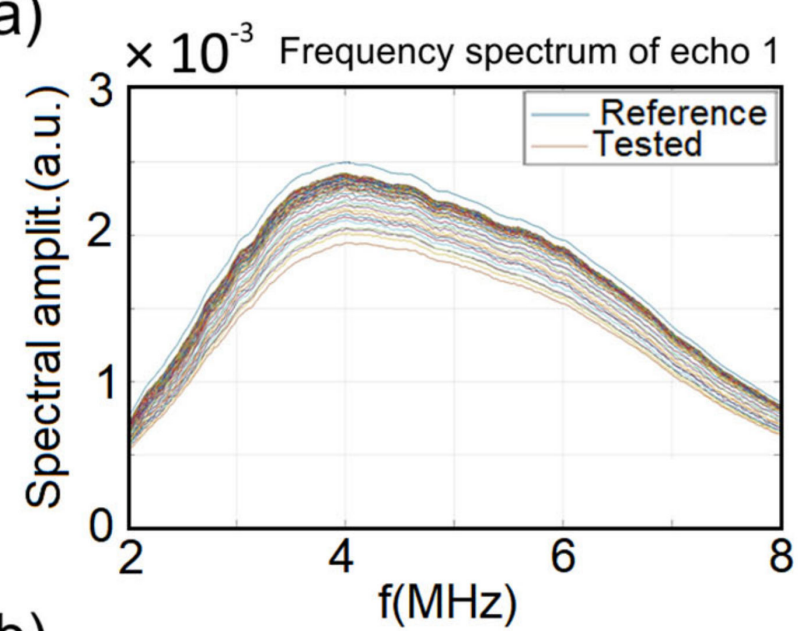

(b)

Time averaged attenuation of echo 1 and water

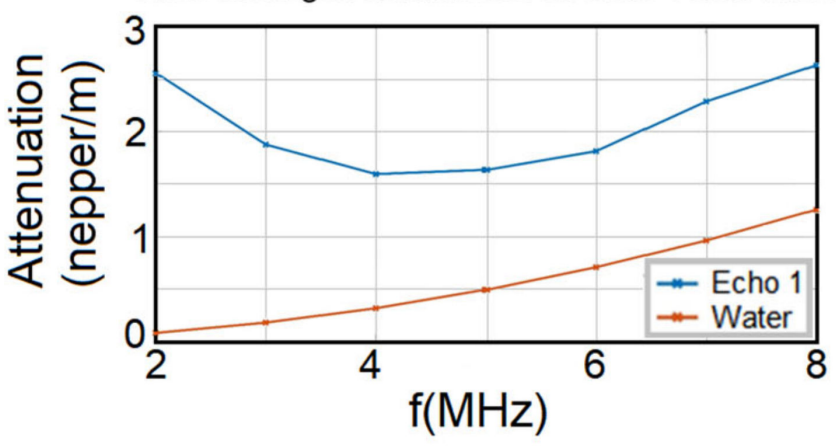

(c)

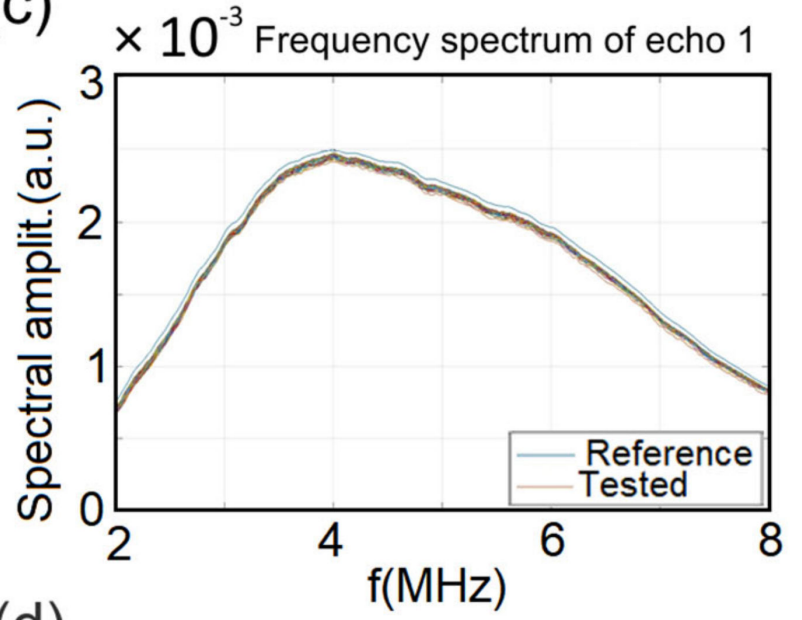

(d)

Time averaged attenuation of echo 1 and water

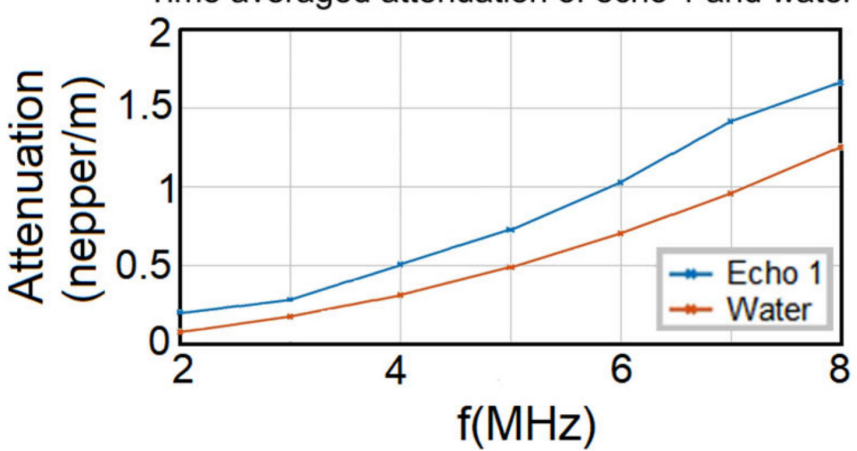

Figure 10. Frequency spectrum of echo 1 before (a) and after lead removal (c). Time averaged attenuation of echo 1 and water before (b) and after lead removal (d).

The efficiency of the HAp-CTAB biocomposite in removing lead ions from contaminated water was also highlighted in Figure 10b, which shows the time-averaged evolution of the spectral attenuation of echo 1 . The maximum attenuation at $2 \mathrm{MHz}$ in lead-polluted water was $2.56 \mathrm{~Np} / \mathrm{m}$ (Figure 10b). After removing the lead, the maximum attenuation at $2 \mathrm{MHz}$ was equal to $0.24 \mathrm{~Np} / \mathrm{m}$, a value very close to that of the double distilled 
water (Figure 10d). Moreover, in the case of polluted water, a minimum attenuation at $4 \mathrm{MHz}$ was observed. On the other hand, the time-averaged evolution of the spectral attenuation of echo 1 for the decontaminated water sample followed that of the reference water (Figure 10d).

Non-destructive ultrasound studies could provide important information about solutions and suspensions because the ultrasound velocity through solutions and suspensions in the linear approximation of small perturbations depends on the average density and average compressibility [68-70]. The study on "removal of zinc ions using hydroxyapatite and study of ultrasound behavior of aqueous media" presented the experimental results of ultrasound measurements on water, contaminated water, and water after decontamination by temporal signal analysis allows determining the time differences between equivalent echoes in different fluids, with an accuracy of $1 \mathrm{~ns}$ [70]. In a recent study on "removal and oxidation of As (III) from water using iron oxide coated CTAB as adsorbent", the efficiency of the biocomposite in the elimination of arsenic ions was evaluated by non-destructive ultrasound studies based on the time-mediated evolution of spectral attenuation of echo 1 and double distilled water [71]. The stability parameter calculated for the first echo clearly highlighted the efficiency of the biocomposite in removing arsenic from polluted water [71].

Furthermore, the cytotoxicity of the HAp-CTAB nanocomposites was assessed by performing in vitro cytotoxicity studies on HAp-CTAB nanocomposites, solutions contaminated with various concentrations of $\mathrm{Pb}^{2+}$ ions, and decontaminated aqueous solutions. For this purpose, the in vitro cell viability of HeLa cell incubated for $24 \mathrm{~h}$ with HAp-CTAB nanocomposites, lead-contaminated solutions, and decontaminated solutions using HApCTAB nanocomposites was investigated using the MTT assay. The results of the MTT assay, regarding the HeLa cell viability after treatment with solutions contaminated with

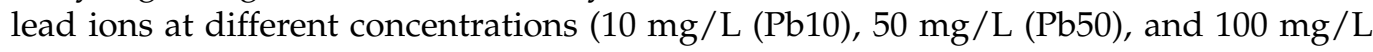
$(\mathrm{Pb} 100))$ and also with the decontaminated solutions using HAp-CTAB nanocomposites (HAp-CTAB_Pb10, HAp-CTAB_Pb50, and HAp-CTAB_Pb100) are presented in Figure 11. The results of the MTT assay highlighted that the solutions contaminated with lead ions exhibited a higher toxicity towards HeLa cells. In addition, the data suggested that the HeLa cell viability has been greatly influenced by the lead ions concentration. The MTT results showed that the cell viability of the HeLa cells decreased considerably with the increase of the lead ions concentrations from $20 \%$ for the solutions containing $20 \mathrm{mg} / \mathrm{L}$ to $1 \%$ for the solutions containing $100 \mathrm{mg} / \mathrm{L}$ lead ions. The HeLa culture that has not been treated with any sample was used as control, and all the other values were normalized according to it. Lead is a non-biodegradable naturally occurring element that has been reported to have a high degree of toxicity [72-74]. Studies have reported that even small doses of lead could produce devastating effects on various organ systems such as the nervous system, the red blood cells, hematopoietic system, endocrine system, reproductive system, and the kidneys, which are considered to be the primary targets of lead toxicity [72-74]. 


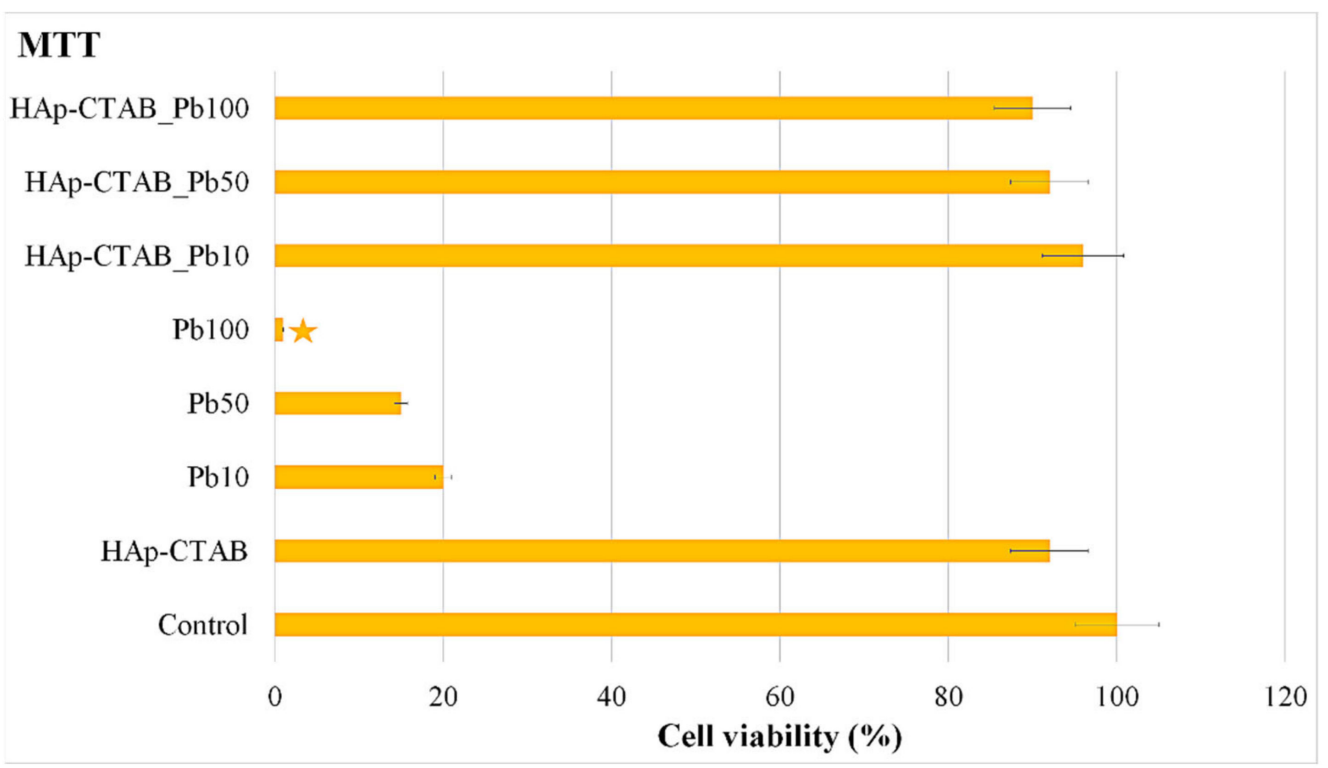

Figure 11. Cell viability of HeLa cells incubated with water in the presence of HAp-CTAB nanocomposites, $\mathrm{Pb}^{2+}$ contaminated solutions, and decontaminated solutions using HAp-CTAB nanocomposites. HeLa cell culture was used as the control.

More than that, the results of the MTT assays conducted on the aqueous decontaminated solutions using HAp-CTAB nanocomposites are also presented in Figure 11. The data showed that the decontaminated solutions did not exhibit a noticeable effect on the cell viability of the HeLa culture after $24 \mathrm{~h}$ of incubation. The MTT assay results highlighted that for the decontaminated solutions, the cell viability of the HeLa culture was above $90 \%$. These results suggested that the HAp-CTAB nanocomposites could be used for the removal of lead ions from contaminated solutions, without inducing cytotoxic effects on the living organisms. Moreover, the cytotoxicity of the HAp-CTAB nanocomposites was also studied, and the results of the MTT assay are depicted in Figure 11. The data revealed that HAp-CTAB nanocomposites exhibited no toxicity on HeLa cells after $24 \mathrm{~h}$ of incubation.

Complementary information regarding the toxicity of the HAp-CTAB nanocomposites and also of the lead-contaminated and decontaminated solutions was obtained by visualizing the HeLa cells after $24 \mathrm{~h}$ of incubation with the aid of an optical microscope. The morphology of the HeLa cells incubated with lead-contaminated solutions at a concentration of $50 \mathrm{mg} / \mathrm{L}$, decontaminated solutions using HAp-CTAB nanocomposites, and HAp-CTAB nanocomposites are depicted in Figure 12.

The visualization of the HeLa cells after $24 \mathrm{~h}$ of incubation with the samples confirmed the results from the quantitative MTT assay and suggested that HAp-CTAB nanocomposites did not induced any noticeable morphological changes of the HeLa cells after $24 \mathrm{~h}$ of incubation. The morphology of HeLa cells was also not modified after being incubated with the decontaminated solutions. On the other hand, the results of the optical microscopy visualization emphasized that the morphology of the HeLa cells incubated with the leadcontaminated aqueous solution was significantly altered indicating that the lead ions exhibited a strong toxic effect on the HeLa cells morphology. The results are in good agreement with the data obtained from the MTT cytotoxicity assay and with previously reported data regarding the lead toxicity on different cell types $[19,75-78]$. The preliminary findings regarding the toxicity of the HAp-CTAB combined with their removal efficiency demonstrated that they could be suitable in the development of novel environmental remediation technologies, which are of great interest worldwide. 

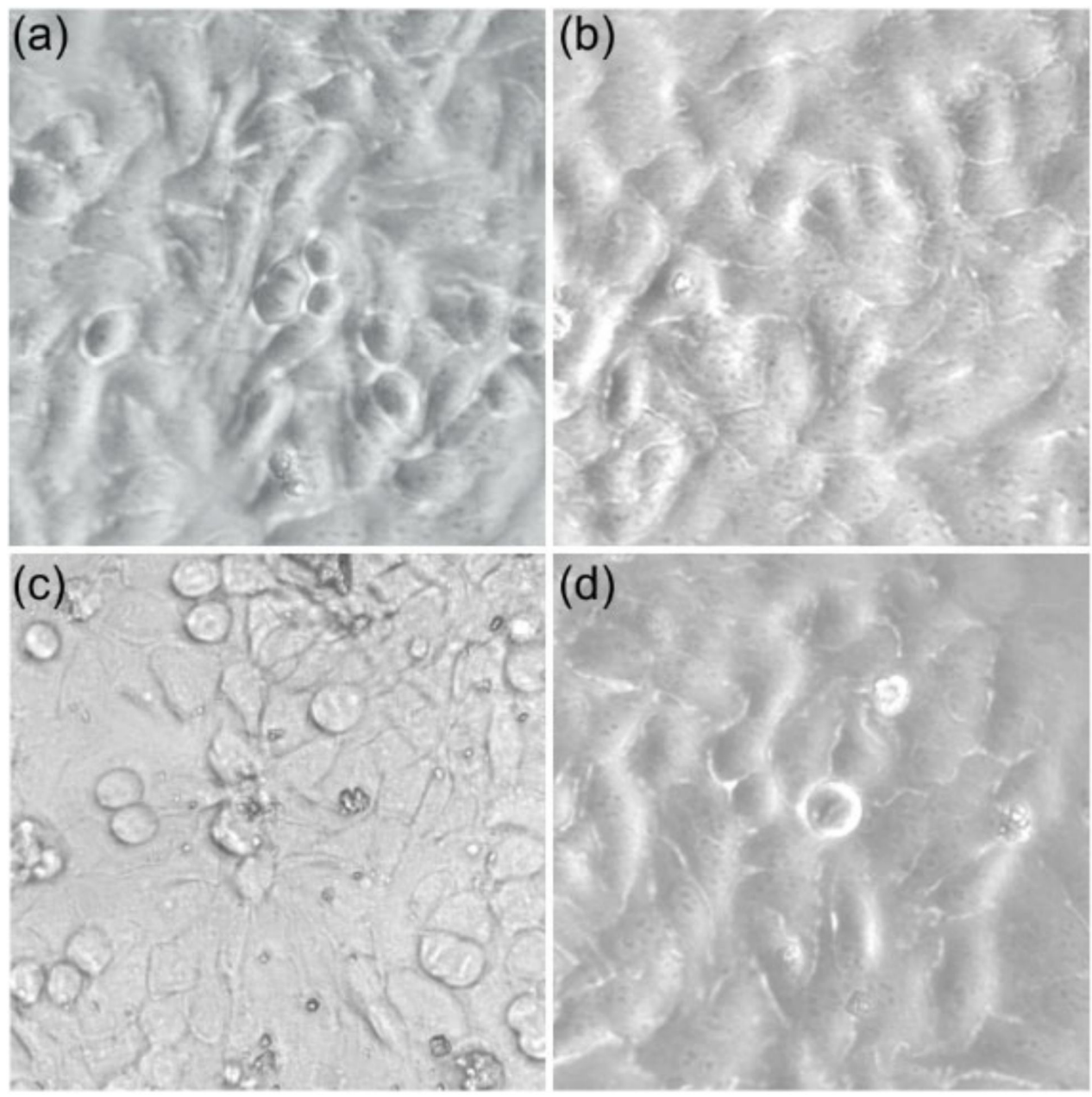

Figure 12. The morphology of the HeLa cells used as control (a); incubated with HAp-CTAB nanocomposites in water $(\mathbf{b})$, incubated with $\mathrm{Pb}^{2+}$ contaminated solutions (c), and incubated with solutions decontaminated using HAp-CTAB nanocomposites (d).

Our preliminary results highlight that HAp-CTAB nanocomposites exhibited a good affinity towards lead ions without exhibiting toxicity against HeLa cells, thus being promising leads for the successful development of new water remediation technologies.

\section{Conclusions}

The present study was aimed to obtain, for the first time, a porous bioceramic composite based on hydroxyapatite (HAp) with cetyl trimethyl ammonium bromide (CTAB) as a surfactant, using the co-precipitation method. The HAp-CTAB biocomposite was used as an effective adsorbent in order to remove the lead ions from contaminated aqueous solution. The calculated values of lattice parameters of HAp-CTAB composite were in agreement with the lattice parameters of pure hydroxyapatite. The FTIR studies confirmed the formation of the HAp-CTAB composite. The porosity of HAp-CTAB has been demonstrated by $\mathrm{N}_{2}$ adsorption/desorption analysis.

Furthermore, the HAp-CTAB nanocomposites' capacity of lead adsorption from aqueous solutions was studied by batch adsorption experiments. The adsorption of lead ions followed the Langmuir adsorption isotherm model, suggesting that the HAp-CTAB nanocomposites presented a high affinity towards lead ions and have successfully removed them from the contaminated aqueous solutions. The non-destructive ultrasound studies confirmed the effectiveness of HAp-CTAB in removing lead ions from an aqueous solution. In addition, the HAp-CTAB nanocomposites proved to be not cytotoxic, while the lead- 
contaminated solutions presented a high toxicity against HeLa cells, the toxicity degree being strongly correlated with the lead ions concentration.

Author Contributions: Conceptualization, S.-A.P., S.L.I., and M.M.-H.; methodology, S.-A.P., S.L.I., C.S.C., M.C.C., and M.M.-H.; software, S.-A.P.; validation, S.-A.P., C.S.C., S.L.I., M.M.-H., and M.C.C.; formal analysis, S.-A.P. and S.L.I.; investigation, S.L.I., S.-A.P., C.S.C., M.M.-H., M.L.B., and M.C.C.; resources, S.-A.P., S.L.I., and M.M.-H; data curation, S.-A.P., S.L.I., S.-A.P., M.M.-H., and M.C.C.; writing-original draft preparation, S.-A.P and S.L.I.; writing-review and editing, S.-A.P., S.L.I., C.S.C., M.M.-H., and M.C.C.; visualization, S.L.I., S.-A.P., M.M.-H., C.S.C., M.L.B., and M.C.C.; supervision, S.L.I., M.M.-H., and S.-A.P.; project administration, S.L.I.; funding acquisition, S.L.I. and M.C.C. All authors have read and agreed to the published version of the manuscript.

Funding: This research was funded by the Romanian Ministry of Research and Innovation through the project PN-III-P1-1.2-PCCDI-2017-0629/contract no. 43PCCDI/2018.

Institutional Review Board Statement: Not applicable.

Informed Consent Statement: Not applicable.

Data Availability Statement: Data is available on demand from the corresponding author.

Acknowledgments: This work was supported by the Romanian Ministry of Research and Innovation through the projects PN-III-P1-1.2-PCCDI-2017-0629/contract no. 43PCCDI/2018 and PN-III-P1-1.2PCCDI-2017-0134, Contract No. 23PCCDI/2018, PN-III-P4-IDPCCF-2016-0114 POSCCE (RADAR) and CNFIS-FDI-2021-0405.

Conflicts of Interest: The authors declare no conflict of interest.

\section{References}

1. Dexiang, L.; Zheng, W.; Li, X.; Yang, Q.; Yue, X.; Guo, L.; Zeng, G. Removal of lead(II) from aqueous solutions using carbonate hydroxyapatite extracted from eggshell waste. J. Hazard. Mater 2010, 177, 126-130.

2. Jang, S.H.; Min, B.G.; Jeong, Y.G.; Lyoo, W.S.; Lee, S.C. Removal of lead ions in aqueous solution by hydroxyapatite/polyurethane composite foams. J. Hazard. Mater. 2008, 152, 1285-1292. [CrossRef]

3. Ghita, R.V.; Iconaru, S.L.; Popa, C.L.; Costescu, A.; Le Coustumer, P.; Motelica-Heino, M.; Ciobanu, C.S.J. Sm: HAp nanopowders present antibacterial activity against enterococcus faecalis. Nanomaterials 2014, 2014, 1-7. [CrossRef]

4. Günay, A.; Arslankaya, A.; Tosun, I. Lead removal from aqueous solution by natural and pretreated clinoptilolite: Adsorption equilibrium and kinetics. J. Hazard. Mater. 2007, 146, 362-371. [CrossRef] [PubMed]

5. Patrinoiu, G.; Calderón-Moreno, J.M.; Chifiriuc, C.M.; Saviuc, C.; Birjega, R.; Carp, O. Tunable ZnO spheres with high anti-biofilm and antibacterial activity via a simple green hydrothermall. J. Colloid. Interface. Sci. 2016, 462, 64-74. [CrossRef]

6. Bailey, S.E.; Olin, T.J.; Bricka, R.M.; Adrian, D.D. A review of potentially low-cost sorbents for heavy metals. Water Res. 1999, 33, 2469-2479. [CrossRef]

7. Luo, J.; Yu, D.; Hristovski, K.D.; Fu, K.; Shen, Y.; Westerhoff, P.; Crittenden, J.C. Critical Review of Advances in Engineering Nanomaterial Adsorbents for Metal Removal and Recovery from Water: Mechanism Identification and Engineering Design. Environ. Sci. Technol. 2021, 55, 4287-4304. [CrossRef]

8. Luo, J.; Fu, K.; Yu, D.; Hristovski, K.D.; Westerhoff, P.; Crittenden, J.C. Review of Advances in Engineering Nanomaterial Adsorbents for Metal Removal and Recovery from Water: Synthesis and Microstructure Impacts. ACS EST Engg. 2021, 1, 623-661. [CrossRef]

9. Ma, Q.Y.; Traina, S.J.; Logan, T.J.; Ryan, J. In situ lead immobilization by apatite. Environ. Sci. Technol. 1993, 27, 1803-1810. [CrossRef]

10. Zhang, P.; Ryan, J.A.; Yang, J. In Vitro Soil Pb Solubility in the Presence of Hydroxyapatite. Environ. Sci. Technol. 1998, 32, 2763-2768. [CrossRef]

11. Mihai, M.M.; Holban, A.M.; Giurcăneanu, C.; Popa, L.G.; Buzea, M.; Filipov, M.; Lazăr, V.; Chifiriuc, M.C.; Popa, M.I. Identification and phenotypic characterization of the most frequent bacterial etiologies in chronic skin ulcers. Rom. J. Morphol. Embryol 2014, 55, 1401-1408.

12. Choi, S.; Jeong, Y. The Removal of Heavy Metals in Aqueous Solution by Hydroxyapatite/Cellulose Composite. Fibers Polym. 2008, 9, 267-270. [CrossRef]

13. Yu, D.; Wang, Y.; Wu, M.; Zhang, L.; Wang, L.; Ni, H. Surface functionalization of cellulose with hyperbranched polyamide for efficient adsorption of organic dyes and heavy metals. J. Clean. Prod. 2019, 232, 774-783. [CrossRef]

14. Ciobanu, C.S.; Iconaru, S.L.; Popa, C.L.; Costescu, A.; Motelica-Heino, M.; Predoi, D. Porous Methyltrimethoxysilane Coated Nanoscale-Hydroxyapatite for Removing Lead Ions from Aqueous Solutions. J. Nanomater. 2014, 2014, 361061. [CrossRef] 
15. García, C.; García, C.; Paucar, C. Controlling morphology of hydroxyapatite nanoparticles through hydrothermal microemulsion chemical synthesis. Inorg. Chem. Commun. 2012, 20, 90-92. [CrossRef]

16. Liu, Y.; Hou, D.; Wang, G. A simple wet chemical synthesis and characterization of hydroxyapatite nanorods. Mater. Chem. Phys. 2004, 86, 69-73. [CrossRef]

17. Shih, W.-J.; Wang, M.-C.; Hon, M.-H. Morphology and crystallinity of the nanosized hydroxyapatite synthesized by hydrolysis using cetyltrimethylammonium bromide (CTAB) as a surfactant. J. Cryst. Growth 2005, 275, e2339-e2344. [CrossRef]

18. Venditti, F.; Ceglie, A.; Palazzo, G.; Colafemmina, G.; Lopez, F. Removal of chromate from water by a new CTAB-silica gelatin composite. J. Colloid Interface Sci. 2007, 310, 353-361. [CrossRef]

19. Ercal, N.; Gurer-Orhan, H.; Aykin-Burns, N. Toxic Metals and Oxidative Stress Part I: Mechanisms Involved in Metal induced Oxidative Damage. Curr. Top. Med. Chem. 2001, 1, 529-539. [CrossRef]

20. Gurer, H.; Ercal, N. Can antioxidants be beneficial in the treatment of lead poisoning. Free Radic. Biol. Med. 2000, 29, 927-945. [CrossRef]

21. Yiin, S.J.; Lin, T.H. Lead-catalyzed peroxidation ofessential unsaturated fatty acid. Biol. Trace Elem. Res. 1995, 50, 167-172. [CrossRef]

22. Patterson, A. The Scherrer formula for x-ray particle size determination. Phys. Rev. 1939, 56, 978-982. [CrossRef]

23. Brunauer, S.; Emmett, P.H.; Teller, E. Adsorption of Gases in Multimolecular Layers. J. Am. Chem. Soc. 1938, 60, 309-319. [CrossRef]

24. Barrett, E.P.; Joyner, L.G.; Halenda, P.P. The Determination of Pore Volume and Area Distributions in Porous Substances 0.1. Computations from Nitrogen Isotherms. J. Am. Chem. Soc. 1951, 73, 373-380.

25. Predoi, D.; Iconaru, S.L.; Predoi, M.V. Dextran-coated zinc-doped hydroxyapatite for biomedical applications. Polymers 2019, 11, 886. [CrossRef]

26. Ncibi, M.C. Applicability of some statistical tools to predict optimum adsorption isotherm after linear and non-linear regression analysis. J. Hazard. Mater. 2008, 153, 207-212. [CrossRef] [PubMed]

27. Allen, S.J.; Mckay, G.; Porter, J.F. Adsorption isotherm models for basic dyea dsorption by peat in single and binary component systems. J. Colloid Interface Sci. 2004, 280, 322-333. [CrossRef] [PubMed]

28. Langmuir, I. The adsorption of gases on plane surfaces of glass, mica and platinum. J. Am. Chem. Soc. 1918, 40, 1361-1403. [CrossRef]

29. Ho, Y.S.; Huang, C.T.; Huang, H.W. Equilibrium sorption isotherm for metal ions on tree fern. Process. Biochem. 2002, 37, 1421-1430. [CrossRef]

30. Meroufel, B.; Benali, O.; Benyahia, M.; Benmoussa, Y.; Zenasni, M.A. Adsorptive removal of anionic dye from aqueous solutions by Algerian kaolin: Characteristics, isotherm, kinetic and thermodynamic studies. J. Mater. Environ. Sci. 2013, 44, 482-491.

31. Predoi, D.; Vatasescu-Balcan, R.A. Osteoblast interaction with iron oxide nanoparticles coated with dextrin in cell culture. $J$. Optoelectron. Adv. Mater. 2008, 10, 152-157.

32. Prodan, A.M.; Beuran, M.; Turculet, C.S.; Popa, M.; Andronescu, E.; Bleotu, C.; Raita, S.M.; Soare, M.; Lupescu, O. In vitro evaluation of glycerol coated iron oxide nanoparticles in solution. Rom. Biotechnol. Lett. 2018, 23, 13901-13908.

33. Iconaru, S.L.; Turculet, C.; Le Coustumer, P.; Bleotu, C.; Chifiriuc, M.C.; Lazar, V.; Surugiu, A.; Badea, M.; Iordache, F.M.; Soare, M.; et al. Biological studies on dextrin coated iron oxide nanoparticles. Rom. Rep. Phys. 2016, 6868, 1536-1544.

34. Prodan, A.M.; Iconaru, S.L.; Chifiriuc, C.M.; Bleotu, C.; Ciobanu, S.C.; Motelica-Heino, M.; Sizaret, S.; Predoi, D. Magnetic Properties and Biological Activity Evaluation of Iron Oxide Nanoparticles. J. Nanomater. 2013, 2013, 1-7. [CrossRef]

35. Yao, J.; Tjandra, W.; Chen, Y.Z.; Tam, K.C.; Ma, J.; Soh, B. Hydroxyapatite Nanostructure Material Derived Using Cationic Surfactant as a Template. J. Mater. Chem. 2003, 13, 3053-3057. [CrossRef]

36. Kay, M.I.; Young, R.A.; Posner, A.S. Crystal Structure of Hydroxyapatite. Nature 1964, 204, 1050-1052. [CrossRef]

37. Fowler, B.O. Infrared Studies of Apatites. I. Vibrational Assignments for Calcium, Strontium, and Barium Hydroxyapatites Utilizing Isotopic Substitution. Inorg. Chem. 1974, 13, 194-207. [CrossRef]

38. Salimi, E.; Javadpour, J.; Anbia, M. Template-Based Synthesis of Nanoporous Hydroxyapatite. ISRN Ceram. 2012, $2012,1-6$. [CrossRef]

39. Costescu, A.; Ciobanu, C.S.; Iconaru, S.L.; Ghita, R.V.; Chifiriuc, M.C.; Marutescu, L.G.; Predoi, D. Fabrication, characterization, and antimicrobial activity, evaluation of low silver concentrations in silver-doped hydroxyapatite nanoparticles. J. Nanomater. 2013, 2013, 5. [CrossRef]

40. Predoi, D.; Iconaru, S.L.; Predoi, M.V.; Motelica-Heino, M.; Buton, N.; Megier, C. Obtaining and Characterizing Thin Layers of Magnesium Doped Hydroxyapatite by Dip Coating Procedure. Coatings 2020, 10, 510. [CrossRef]

41. Predoi, D.; Iconaru, S.L.; Predoi, M.V. Fabrication of Silver- and Zinc-Doped Hydroxyapatite Coatings for Enhancing Antimicrobial Effect. Coatings 2020, 10, 905. [CrossRef]

42. Thommes, M.; Kaneko, K.; Neimark, A.V.; Olivier, J.P.; Rodriguez-Reinoso, F.; Rouquerol, J.; Sing, K.S. Physisorption ofgases, with special reference to the evaluation of surface area and pore size distribution (IUPAC Technical Report). Pure Appl. Chem. 2015, 87, 1051-1069. [CrossRef]

43. Silvestre-Albero, J.; Silvestre-Albero, A.M.; Llewellyn, P.L.; Rodríguez-Reinoso, F. High-resolution N2 adsorption isotherms at77.4 K: Critical effect of the He used during calibration. J. Phys. Chem. C 2013, 117, 16885-16889. [CrossRef] 
44. Sambudi, N.S.; Cho, S.; Cho, K. Porous hollow hydroxyapatite microspheres synthesized by spray pyrolysis using a microalgatemplate: Preparation, drug delivery, and bioactivity. RSC Adv. 2016, 6, 43041-43048. [CrossRef]

45. Uota, M.; Arakawa, H.; Kitamura, N.; Yoshimura, T.; Tanaka, J.; Kijima, T. Synthesis of high surface area hydroxyapatite nanoparticles by mixed surfactant-mediated approach. Langmuir 2005, 21, 4724-4728. [CrossRef] [PubMed]

46. Zhang, Z.; Li, M.; Chen, W.; Zhu, S.; Liu, N.; Zhu, L. Immobilization of lead and cadmium from aqueous solution and contaminated sediment using nano-hydroxyapatite. Environ. Pollut. 2010, 158, 514-519. [CrossRef] [PubMed]

47. Gandhi, M.R.; Meenakshi, G.N.K.S. Removal of copper (II) using chitin/chitosan nano-hydroxyapatite composite. Int. J. Biol. Macromol. 2011, 48, 119-124. [CrossRef]

48. Vila, M.; Sánchez-Salcedo, S.; Vallet-Regí, M. Hydroxyapatite foams for the immobilization of heavy metals: From waters to the human body. Inorg. Chim. Acta 2012, 393. [CrossRef]

49. Hafsteinsdóttir, E.G.; Camenzuli, D.; Rocavert, A.L.; Walworth, J.; Gore, D.B. Chemical immobilization of metals and metalloids by phosphates. Appl. Geochem. 2015, 59, 47-62. [CrossRef]

50. Nishiyama, Y.; Hanafusa, T.; Yamashita, J.; Yamamoto, Y.; Ono, T. Adsorption and removal of strontium in aqueous solution by synthetic hydroxyapatite. J. Radioanal. Nucl. Chem. 2016, 307, 1279-1285. [CrossRef]

51. Malek, A.; Farooq, S. Comparison of isotherm models for hydrocarbon adsorption on activated carbon. AIChE J. 1996, 42, 3191-3201. [CrossRef]

52. Langmuir, I. The constitution and fundamental properties of solids and liquids. J. Am. Chem. Soc. 1916, 38, 2221-2295. [CrossRef]

53. Bulut, E.; Ozacar, M.; Sengil, I.A. Adsorption of malachite green onto bentonite: Equilibrium and kinetic studies and process design. Micropor. Mesopor. Mater. 2008, 115, 234-246. [CrossRef]

54. Ayawei, N.; Ebelegi, A.N.; Wankasi, D. Modelling and Interpretation of Adsorption Isotherms. J. Chem. 2017, $2017,1-11$. [CrossRef]

55. Vijayaraghavan, K.; Padmesh, T.V.N.; Palanivelu, K.; Velan, M. Biosorption of nickel (II) ions onto Sargassum wightii: Application of two-parameterand three parameter isotherm models. J. Hazard. Mater. 2006, B133, 304-308. [CrossRef]

56. Kundu, S.; Gupta, A.K. Arsenic adsorption onto iron oxide-coated cement (IOCC): Regression analysis of equilibrium data with several isotherm models and their optimization. Chem. Eng. J. 2006, 122, 93-106. [CrossRef]

57. Iconaru, S.L.; Motelica-Heino, M.; Guegan, R.; Beuran, M.; Costescu, A.; Predoi, D. Adsorption of Pb (II) Ions onto Hydroxyapatite Nanopowders in Aqueous Solutions. Materials 2018, 11, 2204. [CrossRef]

58. Predoi, D.; Predoi, M.V.; Iconaru, S.L.; Ech Cherif El Kettani, M.; Leduc, D.; Prodan, A.M. Ultrasonic Measurements on $\beta$ Cyclodextrin/Hydroxyapatite Composites for Potential Water Depollution. Materials 2017, 10, 681. [CrossRef]

59. Lee, C.-K.; Kim, H.-S.; Kwon, J.-H. The removal of heavy metals using hydroxyapatite. Environ Eng. Res. 2005, 10, $205-212$. [CrossRef]

60. Ghita, R.V.; Iconaru, S.L.; Popa, C.L.; Costescu, A.; Le Coustumer, P.; Motelica-Heino, M.; Ciobanu, C.S. Tetraethyl Orthosilicate Coated Hydroxyapatite Powders for Lead Ions Removal from Aqueous Solutions. J. Nanomater. 2014, 2014, 1-8. [CrossRef]

61. Ho, Y.S. Selection of optimum sorption isotherm. Carbon 2004, 42, 2115-2116. [CrossRef]

62. He, J.; Hong, S.; Zhang, L.; Gan, F.; Ho, Y.-S. Equilibrium and Thermodynamic parameters of adsorption of merhylene blue onto rectorite. Fresen. Environ. Bull. 2010, 19, 2651-2656.

63. Minh, D.P.; Tran, N.D.; Nzihou, A.; Sharrock, P. Hydroxyapatite gel for the improved removal of $\mathrm{Pb}^{2+}$ ions from aqueous. Solution Chem. Eng. J. 2013, 232, 128-138. [CrossRef]

64. Freundlich, H.M.F. Over the adsorption in solution. J. Phys. Chem. 1906, 57, 385-471.

65. Adamson, A.W.; Gast, A.P. Physical Chemistry of Surfaces, 6th ed.; Wiley-Interscience: New York, NY, USA, 1997.

66. Voudrias, E.; Ytianos, F.; Bozani, E. Sorption Description isotherms of Dyes from aqueous solutions and Waste Waters with Different Sorbent materials. Global Nest. Int. J. 2002, 4, 75-83.

67. Mohan, S.; Karthikeyan, J. Removal of lignin and tannin color from aqueous solution by adsorption on to activated carbon solution by adsorption on to activated charcoal. Environ. Pollut. 1997, 97, 183-187. [CrossRef]

68. Khayyun, T.S.; Mseer, A.S. Comparison of the experimental results with the Langmuir and Freundlich models for copper removal on limestone adsorbent. Appl. Water Sci. 2019, 9, 1-8. [CrossRef]

69. Urick, R.J. The absorption of sound in suspensions of irregular particles. J. Acoust. Soc. Am. 1948, 20, 283-289. [CrossRef]

70. Iconaru, S.L.; Motelica-Heino, M.; Guegan, R.; Predoi, M.V.; Prodan, A.M.; Predoi, D. Removal of Zinc Ions Using Hydroxyapatite and Study of Ultrasound Behavior of Aqueous Media. Materials 2018, 11, 1350. [CrossRef]

71. Predoi, D.; Iconaru, S.L.; Predoi, M.V.; Motelica-Heino, M. Removal and Oxidation of As(III) from Water Using Iron Oxide Coated CTAB as Adsorbent. Polymers 2020, 12, 1687. [CrossRef] [PubMed]

72. Tchounwou, P.B.; Yedjou, C.G.; Foxx, D.N.; Ishaque, A.B.; Shen, E. Lead-induced cytotoxicity and transcriptional activation of stress genes in human liver carcinoma (HepG2) cells. Mol. Cell. Biochem. 2004, 255, 161-170. [CrossRef] [PubMed]

73. Agency for Toxic Substances and Disease Registry (ATSDR). Toxicological Profile for Lead; Public Health Service, U.S. Department of Health and Human Services: Atlanta, GA, USA, 1999.

74. Pirkle, J.L.; Kaufmann, R.B.; Brody, D.J.; Hickman, T.; Gunter, E.W.; Paschal, D.C. Exposure of the U.S. population to lead, 1991-1994. Environ. Health Perspect. 1998, 106, 745-750. [CrossRef] 
75. Silbergeld, E.K. Facilitative mechanisms of lead as a carcinogen. Mutat. Res. 2003, 533, 121-133. [CrossRef] [PubMed]

76. Hartwig, A.; Schlepegrell, R.; Beyersmann, D. Indirect mechanism of lead-induced genotoxicity in cultured mammalian cells. Mutat. Res. 1990, 241, 75-82. [CrossRef]

77. Frenkel, G.D.; Middleton, C. Effects of lead acetate on DNA and RNA synthesis by intact HeLa cells, isolated nuclei and purified polymerases. Biochem. Pharmacol. 1987, 36, 265-268. [CrossRef]

78. Pounds, J.G.; Long, G.J.; Rosent, J.F. Cellular and Molecular Toxicity of Lead in Bone. Environ. Health. Perspect. 1991, 91, 17-32. [CrossRef] [PubMed] 